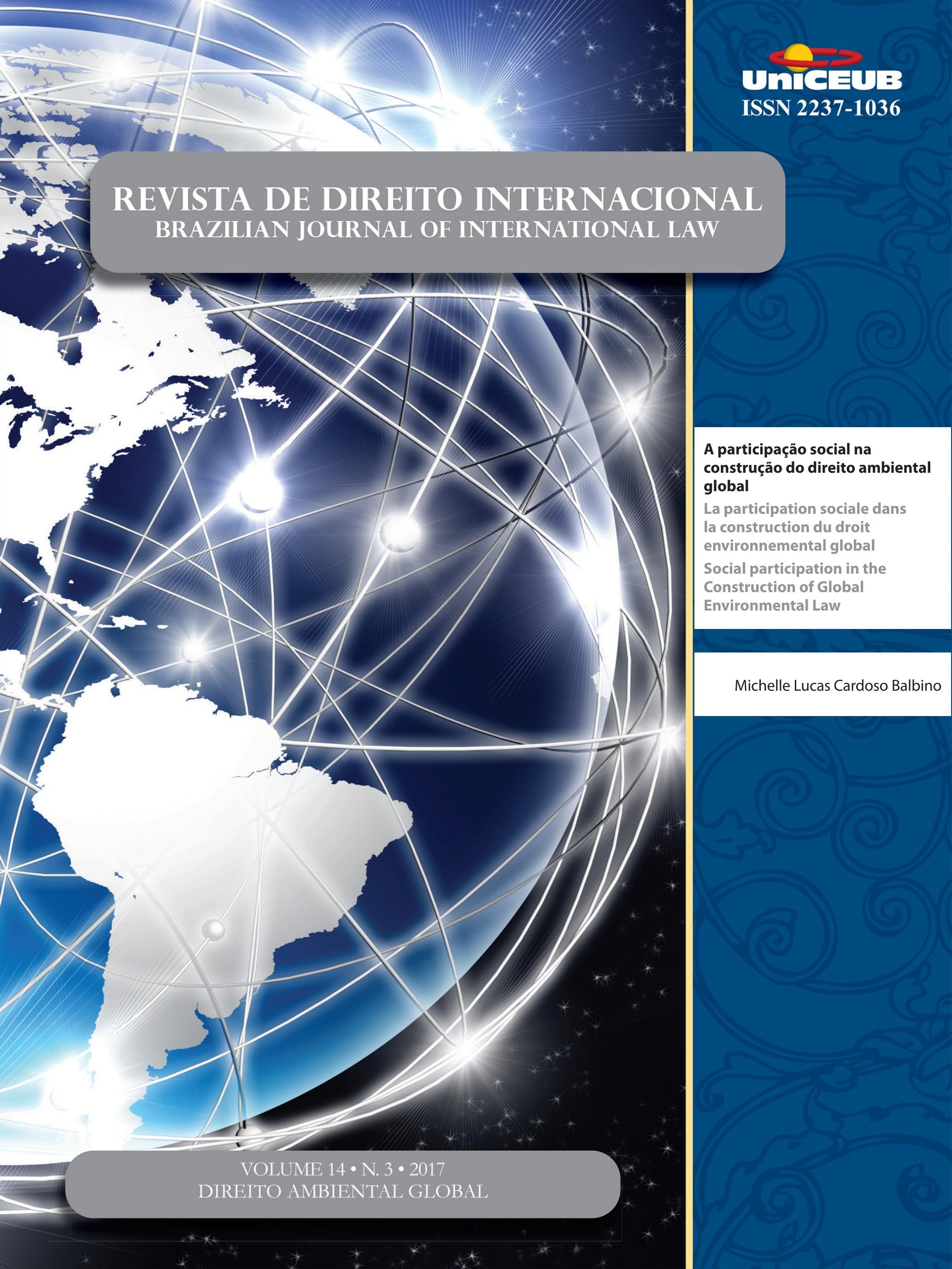




\section{Sumário}

I. Crônicas do Direito Internacional ...............................................1

CRÔNICAS DE DiREITO INTERNACIONAL PÚBLICO ........................................................................ 3

A política australiana de Refúgio e a decisão da Suprema Corte de PAPUA NOVA GUINÉ: A

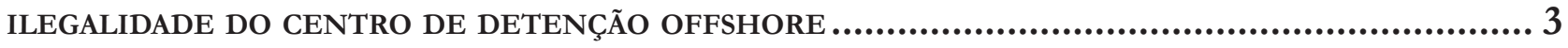

Tarin Cristino Frota Mont'Alverne e Ana Carolina Barbosa Pereira Matos

II. Dossiê especial: Direito Ambiental Global............................................ 7

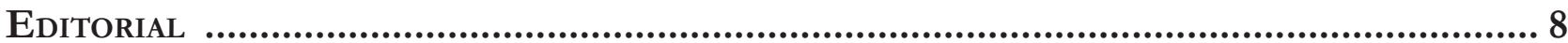

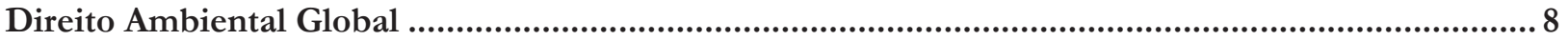

Priscila Pereira de Andrade

Direito Global: UMa TEORIA ADEQUAda PARA SE PENSAR o DiREITO AMBIENTAL? ................10 Arnaud Van Waeyenberge

“Complex is Beautiful": What role for the 2015 Paris Agreement in making the Effective Links within the Climate Regime Complex? .................................................21 Sandrine Maljean-Dubois e Matthieu Wemaëre

UNE ILLUSTRATION DU DROIT GLOBAL, LA LEX MERCATORIA CLIMATIQUE...............................31 Mathilde Hautereau-Boutonnet

OCÉANS ET CHANGEMENTS CLIMATIQUES : RECHERCHER LES INTERACTIONS AU SEIN DE LA FRAGMENTATION DU DROIT INTERNATIONAL

Sophie Gambardella

Une gouvernance globale du Climat par la transparence depuis l'Accord de Paris: Le DROIT GLOBAL DE L'ENVIRONNEMENT COMME SOLFÈGE? .56

Anne-Sofie Tabau 
LA PROGRESSIVE HARMONISATION DES RÈGLES DU PROCÈS ENVIRONNEMENTAL: MANIFESTATION

DE L'ÉMERGENCE D'UN DROIT GLOBAL? ............................................................69

Eve Truilhé-Marengo

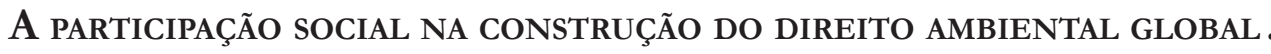
80 Michelle Lucas Cardoso Balbino

A PROTEÇÃo AMBIENTAL COMO EFEITO INDIRETO DO SISTEMA DE GESTÃo DE ENERGIA ISO 50001

Matheus Linck Bassani e Ricardo Serrano Osorio

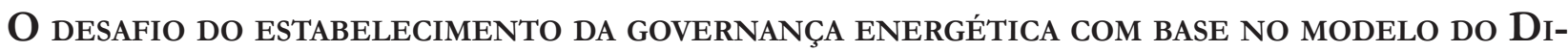
reito Administrativo Global: ESTUdo de CASO DAS ENERgias RENOVÁveis. 122 Alice Rocha da Silva

Othon Pantoja Oliveira de Azevedo

O PRINCÍPIO DA PARTICIPAÇÃo E A CRIAÇÃO E GESTÃo DAS ÁREAS PROTEGIDAS NA PERSPECTIVA DO DIREITO AMBIENTAL GLOBAI

Marcia Dieguez Leuzinger e Solange Teles da Silva

A teoria Ambientalista (GREen theOry) e a COMpetênCia CONSUltiva da CoRTE InTERAmericana de Direitos Humanos: O caso da Colômbia................................................. 148

Eduardo Biacchi Gomes e Ane Elise Brandalise

III. Artigos sobre outros temas....................................................... 160

30 anos do Protocolo de Montreal: Uma história de sucesso do Direito Ambiental

INTERNACIONAL 162

Fernando Rei e Valeria Cristina Farias

MinORIAS NACIONAIS, PROTEÇão INTERNACIONAL E TRANSNACIONALIDADE 182 Ana Maria D'Ávila Lopes e Luis Haroldo Pereira dos Santos Junior

Da relevância dos casos do Desarmamento Nuclear perante a Corte Internacional DE JUSTIÇA 203 Lucas Carlos Lima 
OS CONTROLES DE CONVENCIONALIDADE TRADICIONAL E INTERAMERICANO: INSTITUTOS DISTINTOS OU DUAS FACES DA MESMA MOEDA?

Gilberto Schäfer, Roger Raupp Rios, Paulo Gilberto Cogo Leivas e Jesus Tupã Silveira Gomes

EL SOFT LAW COMO FUENTE DEL DERECHO INTERNACIONAL: REFLEXIONES DESDE LA TEORÍA DE LA COMPLEJIDAD

Rafael Sanz e André Folloni

Ley de rotulación de alimentos de Chile: ¿'Traba comercial o protección de la saLUD?

Nicolás Cobo

IV. RESENHA DE LIVRO.

O CiVILIZAdor gentil das AmÉRICAS: CONSIDERAÇÕes EM TORNO DA OBRA THE HIDDEN HIStory of International LaW in the Americas: Empire and LeGal Networks, de Juan Pablo SCARFI 278

Cicero Krupp da Luz

'Mestizo International Law: A global intelectual history 1842 - 1933' De Autoría de Arnulf Becker-Lorca .283 Jimena Sierra-Camargo

América Latina em Continuidades e rupturas 287 Adriane Sanctis 


\title{
A participação social na construção do direito ambiental global*
}

\author{
La participation sociale dans la construction \\ du droit environnemental global
}

\section{Social participation in the Construction of Global Environmental Law}

Michelle Lucas Cardoso Balbino**

\section{Resumo}

O direito ambiental global, conjunto de princípios jurídicos desenvolvido por sistemas regulatórios ambientais nacionais, internacionais e transnacionais, para a proteção do meio ambiente, é influenciado e influencia uma gama de atores, inclusive, a comunidade e as partes interessadas na proteção ambiental global. A participação social na construção desse direito ambiental global é fator que norteia a elaboração deste artigo, que propõe a análise da utilidade e dos limites da participação social para a construção do direito ambiental global. Na primeira parte do artigo, busca-se a verificação dos critérios de utilidade e instrumentos da participação social, em uma atuação coadjuvante, na construção do direito ambiental global, com acesso à informação e a vulnerabilidade como critérios de condição e justificativa, respectivamente, da participação social na construção do direito ambiental global. A segunda parte do artigo define os limites da participação social na construção do direito ambiental global, definindo limites endógenos e exógenos à participação social. Assim, conclui-se que a participação social é útil para a construção do direito ambiental global, realizando uma atuação bottom-up dessa construção. Contudo, certos aspectos internos e externos da participação social limitam sua atuação sem retirar as contribuições que têm a oferecer.

* Recebido em $02 / 11 / 2017$

Aprovado em 19/12/2017

** Coordenadora do Curso de Direito da Factu/Unaí. Professora Universitária. Advogada. Mestre em Sustentabilidade Socioeconômico e Ambiental pela Escola de Minas pela Universidade Federal de Ouro Preto (Ufop/Ouro Preto). Especialista em Direito, Impacto e Recuperação Ambiental pela Escola de Minas pela Universidade Federal de Ouro Preto (Ufop/ Ouro Preto). Pós-graduada em Gestão Pública Municipal pela Universidade Federal de Uberlândia (UFU/Uberlândia). E-mail: michellebalbino@hotmail.com

\section{RÉSUMÉ}

Le droit environnemental global, l'ensemble des principes juridiques développés par les systèmes de réglementation environnementale nationaux, internationaux et transnationaux pour la protection de l'environnement, est influencé par et influe sur une gamme d'acteurs, notamment les communautés et les acteurs de la protection environnementale global. Cet article propose une analyse de l'utilité et des limites de la participation sociale pour la construction du droit environnemental global. La première partie de l'article examine les critères d'utilité et les instruments de participation sociale, dans le cadre d'une action de soutien vers la construction du droit environnemen- 
tal global en se basant respectivement sur les critères de l'accès à l'information et de vulnérabilité. La deuxième partie de l'article définit les limites de la participation sociale dans la construction du droit environnemental global, soulignant, de la sorte, des limites endogènes et exogènes à la participation sociale. Ainsi, conclut-on que la participation sociale est utile dans la construction du droit environnemental global, en effectuant une performance bottom-up de cette construction. Cependant, certains aspects internes et externes de la participation sociale limitent, leur performance sans enlever les éventuelles contributions.

\section{Abstract}

Global environmental law consists in a set of legal principles developed by national, international and transnational regulatory systems for the protection of the environment, it influences and is influenced by a range of actors, including community and stakeholders interested in global environmental protection. Social participation in the construction of this global environmental law is the object of this article, which proposes the analysis of the utility and limits of social participation for the construction of global environmental law. The first part of the article seeks to verify the utility and instruments of social participation, in supporting the construction of global environmental law. Access to information and vulnerability being respectively the condition and justification of social participation in the construction of global environmental law. The second part of the article defines the limits of social participation in the construction of global environmental law. It defines endogenous and exogenous limits to social participation. Thus, it is concluded that social participation is useful in the construction of global environmental law, performing a bottom-up action to this construction. However, certain internal and external aspects of social participation limit their performance but do not withdraw the contributions it has to offer.

\section{INTRODUÇÃO}

Por meio da globalização das atividades socioeconômicas e da transnacionalização das relações sociais, hou- ve a necessidade de abandonar a ideia de que apenas os Estados Nacionais detêm a prerrogativa de criar e aplicar o direito ${ }^{1}$. Essa globalização disseminou a preocupação com o meio ambiente, influenciando na construção de inúmeras normas ambientais ${ }^{2}$, o que contribuiu para o surgimento do direito ambiental global, conceituado como um conjunto comum de princípios jurídicos substantivos e métodos processuais desenvolvido por sistemas regulatórios ambientais nacionais, internacionais e transnacionais ${ }^{3}$ para a proteção do meio ambiente e gerenciamento de recursos naturais ${ }^{4}$. A característica central do Direito Ambiental Global a capacidade que as normas desenvolvidas em nível local, regional ou mundial afetarem indivíduos e grupos na sociedade, influenciando estes a utilizarem instrumentos legais por meio dos quais eles possam reivindicar seus direitos e interesses na proteção do meio ambiente ${ }^{5}$. Tais questões refletem as transformações do Direito na era global, principalmente em relação à proteção do meio ambiente, indo além dos tradicionais instrumentos de direito internacional, sofrendo influencia tanto de atores estatais, como não estatais ${ }^{6}$.

A forças da globalização acabaram por relativizar as fronteiras estatais de atuação, tendo em vista os avanços quanto aos fluxos globais de informação, comércio, deslocamento populacionais e de afetação de impactos ambientais. Assim, a organização normativa, tradicionalmente organizada em categorias público-privado e interno-internacional, passa a criar vínculos mais estrei-

1 BARBOSA, Luiza Nogueira; MOSCHEN, Valesca Raizer Borges. O direito transnacional ("global law") e a crise de paradigma do estado-centrismo: é possível conceber uma ordem jurídica transnacional? Revista de Direito Internacional, Brasília, v. 13, n. 3, 2016, p. 157.

2 Tal questão é visualizada em nível local, regional, nacional e internacional, tanto por Estados, como por empresas, principalmente quanto da definição de questões sustentáveis e direitos humanos nos Códigos de Ética/Conduta e Relatórios de Sustentabilidade das empresas.

3 Andrade (2016, p. 21) "destaca que o termo "transnacional" supera, portanto, o estudo das relações internacionais exclusivamente interestatais para considerar também o estudo das relações privadas que envolvem atividades transfronteiriças".

4 YANG, Tseming; PERCIVAL, Robert V. The Emergence of Global Environmental Law. Ecology Law Quarterly, v. 36. Research Paper n. 2009-36. Maryland Legal Studies and Vermont Law School Research Paper n. $09-09.15$ out. 2009.

5 HEY, Ellen. Global Environmental Law. 22 nov. 2009. Disponível em: <https://ssrn.com/abstract=1511188>.

6 ANDRADE, Priscila Pereira de. A emergência do direito transnacional ambiental. Revista de Direito Internacional, Brasília, v. 13, n. 3, 2016 p. 19. 
tos entre os sistemas legais internacionais e nacionais ${ }^{7}$. O conteúdo do direito ambiental global interaciona com complexos problemas socioeconômicos, científicos, técnicos e políticos influenciando na tomada de decisões e refletindo em outras áreas do direito, como o direito internacional e comercial ${ }^{8}$. Assim, o Direito Ambiental global é visto como um campo de atuação unificado dos direitos internacional, nacional e transnacional (todos de uma única vez) ${ }^{9}$. Nesse aspecto, verifica-se a existência de uma evolução da legislação ambiental global, principalmente devido à existência de danos ambientais transfronteiriços ${ }^{10}$. Esses danos, normalmente, são causados por produtos e materiais rotineiramente comercializados em todo o mundo como: produtos químicos e bens de consumo (principalmente aqueles que provocam grandes impactos ambientais e apresentam indícios de influência nas alterações climáticas ${ }^{1112}$ ), além de aspectos globais como a legislação e a política de segurança alimentar (reconhecendo a economia global, liberalização do comércio e preocupações com a segurança alimentar e danos ambientais como elemento de direito ambiental global ${ }^{13}$. Outro ponto que fomenta a elaboração global de um direito ambiental é a existência de fatores como a liberalização do comércio e a terceirização da atividade industrial, influenciadas por organizações como a Organização Mundial do Comércio $(\mathrm{OMC})^{14}$ e o Banco Mundial, este último considerado

7 YANG, Tseming; PERCIVAL, Robert V. The Emergence of Global Environmental Law. Ecology Law Quarterly, v. 36. Research Paper n. 2009-36. Maryland Legal Studies and Vermont Law School Research Paper n. $09-09.15$ out. 2009.

8 HEY, Ellen. Global Environmental Law. 22 nov. 2009. Disponível em: <https://ssrn.com/abstract=1511188>.

9 YANG, Tseming; PERCIVAL, Robert V. The Emergence of Global Environmental Law. Ecology Law Quarterly, v. 36. Research Paper n. 2009-36. Maryland Legal Studies and Vermont Law School Research Paper n. $09-09.15$ out. 2009.

10 PERCIVAL, Robert V. Liability for Environmental Harm and Emerging Global Environmental Law. Maryland Journal of International Law, v. 25, p. 37, 2010.

11 BOYD, William. Climate Change, Fragmentation, and the Challenges of Global Environmental Law: Elements of a Post-Copenhagen Assemblage. University of Pennsylvania Journal of International Law, v. 32, n. 2, p. 457, 01 set. 2010. Disponível em: https://ssrn.com/ abstract $=1739123>$.

12 PERCIVAL, Robert V. Liability for Environmental Harm and Emerging Global Environmental Law. Maryland Journal of International Law, v. 25, p. 37, 2010.

13 CZARNEZKI, Jason J.; LIN, Yanmei; FIELD, Cameron. Global Environmental Law: Food Safety \& China. 21 ago. 2012. Vermont Law School Research Paper n. 20-12. Disponível em: <https:// ssrn.com/abstract $=2133551$ or http://dx.doi.org/10.2139/ ssrn.2133551>.

14 YANG, Tseming; PERCIVAL, Robert V. The Emergence of ator central no direito ambiental global quando da sua atuação em países em desenvolvimento ${ }^{15}$.

As preocupações com os danos ambientais transfronteiriços tem estimulado litígios por parte de governos estaduais e entes privados, os quais devem ser responsabilizados por eventuais danos. Contudo, alguns autores denotam a existência de um fracasso do direito internacional público em definir a responsabilidade por danos ambientais transfronteiriços ${ }^{16}$. Tais fatores condicionaram a existência de uma "nova era" de aplicação da legislação ambiental em sede global, o que aqui chamamos de direito ambiental global ${ }^{17}$. Para a estruturação dessa "nova era" da legislação e da regulamentação ambiental em nível global é notório o aumento da colaboração transfronteiriça entre os governos, organizações não governamentais (ONG) e empresas multinacionais, além do estabelecimento de redes ambientais transnacionais $^{18}$. Essa pluralidade de atores é ponto essencial para a estruturação do direito ambiental global. A atuação de partes privadas e atores não estatais representa valor expressivo no litígio ambiental transnacional ${ }^{19}$, até porque, estes precisam mudar seu comportamento se metas ambientais devem ser atingidas ${ }^{20}$.

Como visto, o direito ambiental global é influenciado e influencia uma gama de atores, inclusive, a comunidade e as partes interessadas em relação à proteção ambiental global. Afinal, ninguém pode saber tudo do outro, se nem mesmo sabe tudo de si ou o que está por vim. Nas palavras de Enrique Leff ${ }^{21}$, esse não sa-

Global Environmental Law. Ecology Law Quarterly, v. 36. Research Paper n. 2009-36. Maryland Legal Studies and Vermont Law School Research Paper n. 09-09. 15 out. 2009.

15 HEY, Ellen. Global Environmental Law. 22 nov. 2009. Disponível em: < https://ssrn.com/abstract=1511188>.

16 Dentre eles Robert Percival (2010) e Yang \& Percival (2009). Robert Percival (2010) inclusive aponta que a responsabilidade do Estado tem produzido poucos progressos, sendo que as organizações não-governamentais (ONGs) desempenham um papel importante.

17 PERCIVAL, Robert V. Liability for Environmental Harm and Emerging Global Environmental Law. Maryland Journal of International Law, v. 25, p. 37, 2010.

18 YANG, Tseming; PERCIVAL, Robert V. The Emergence of Global Environmental Law. Ecology Law Quarterly, v. 36. Research Paper n. 2009-36. Maryland Legal Studies and Vermont Law School Research Paper n. 09-09. 15 out. 2009.

19 PERCIVAL, Robert V. Liability for Environmental Harm and Emerging Global Environmental Law. Maryland Journal of International Law, v. 25, p. 37, 2010.

20 HEY, Ellen. Global Environmental Law. 22 nov. 2009. Disponível em: <https://ssrn.com/abstract=1511188>.

21 LEFF, Enrique. Discursos sustentáveis. Tradução Silvana 
ber abre portas para o futuro. Em outra passagem, esse autor define que a solução dos danos transfronteiriços, denominado por ele por crise ambiental, é uma aproximação holística entre métodos interdisciplinares e o pensamento complexo, que somente será alcançado se houver uma real participação social. Assim, a comunidade já tem sua participação ${ }^{22}$ na criação do direito ambiental em dois grandes aspectos: a partir do processo legislativo, com a atuação por iniciativa popular de ações de proteção ambiental, e em relação à participação em órgãos colegiados dotados de poderes normativos, representando, assim, a comunidade na definição normativa. Contudo, a visão limitada dessa participação nos leva a considerar que a participação estaria restrita apenas à formulação de normas para futura proteção ambiental. Porém, a atuação dessa participação vai além da participação da comunidade apenas em relação ao aspecto normativo do direito ambiental. Essa participação também é observada em diversos outros aspectos que possibilita a construção de um direito ambiental global.

Surge, assim, o objetivo geral deste artigo, que propõe a análise da utilidade e dos limites da participação social para a construção do direito ambiental global. Contudo, antes de adentrar ao presente estudo, é importante esclarecer que, para este trabalho, a participação social é considerada gênero, e exige várias espécies, como: participação popular (limitada a comunidade do entorno), participação da sociedade civil organizada (ONG's, sindicatos, grupos formalizados) e participação dos Stakeholders (nestes compreendidos: os denunciantes - pessoa ou grupo que revela informações que demonstram ser ilegais ou imorais —; vítimas — no caso de danos já averiguados — e acionistas $^{2324}$.

O presente trabalho justifica-se pela importância de se estudar as contribuições que a participação social

Cobucci Leite. São Paulo: Cortez, 2010.

22 MILARÉ, Édis. Direito do Ambiente: a gestão ambiental em foco - doutrina, jurisprudência, glossário. 9 ed. São Paulo: Editora Revista dos Tribunais, 2014, p. 195.

23 A estruturação da participação social encontra-se em fase de teste, resultado dos estudos do Projeto de Doutorado intitulado: "A função da participação social na construção jurídica da responsabilidade social empresarial (RSE): rumo à prevenção de impactos socioambientais" do Doutorado em Direito do Centro Universitário de Brasília (UNICEUB) de autoria dessa doutoranda.

24 Yvonne Muller (2016) aponta que a empresa não pode se basear unicamente nos interesses de seus acionistas, mas também nas vontades das partes interessadas, ou seja, aqueles que, direta ou indiretamente, possuem interesses em atividades da empresa. pode fazer em relação à construção do direito ambiental global. Até porque representa uma construção bottom$-u p^{25}$ (de baixo para cima) do direito ambiental global, ou seja, os problemas locais e regionais, que recebem direta participação social, representam componentes do direito ambiental global, pois o foco é o ambiente como um todo, ou seja, todos os males ambientais existentes e em todos os níveis ${ }^{26}$. Assim, a atuação da participação social, caso a caso, em pequenos e grandes impactos, mas com repercussão local e regional, também contribui para a construção do direito ambiental global, pois os riscos sofridos diante dos impactos ambientais são compartilhados por todos ${ }^{27}$, fator que justifica a atuação ativa da participação social frente aos impactos socioambientais em sede local. Até porque, a valorização dos saberes locais garante um aprimoramento do conhecimento científico, em sua pretensão objetiva e universalidade, ao abrir novas perspectivas para compreender e construir um direito ambiental global por meio dos saberes arraigados nas condições ecológicas do desenvolvimento das culturas ${ }^{28}$. Além do que o direito ambiental global se preocupa, cada vez mais, com atividades ocorridas em cada território singular, afinal, os efeitos potencialmente nocivos de tais atividades, mesmo que estes não se apliquem, em sentido físico, para além do território do Estado onde ocorreu o dano em questão, são motivos de preocupação toda a comunidade global ${ }^{29}$.

O presente artigo está dividido em 02 (duas) partes. A primeira busca verificar os critérios de utilidade e instrumentos da participação social na construção bottom- ир do direito ambiental global, tendo o acesso à informação como critério de condição e a vulnerabilidade

25 Ou seja, será por meio da análise da atuação em casos concretos. Observa-se que se trata da realização de uma análise de "baixo para cima" (bottom- $и$ ), com análise de caso a caso, com resultados aferidos após a interconexão destes. Representa a aplicação da indução analítica, como método e estratégia de pesquisa qualitativa deste trabalho. A indução analítica representa, devido a suas múltiplas abordagens, um dos diversos métodos de pesquisa qualitativa existentes (Pinkse; Kuss; Hoffmann, 2009) (Kaushik; Mahadevan, 2011) (Deslauriers, 2014).

26 YANG, Tseming; PERCIVAL, Robert V. The Emergence of Global Environmental Law. Ecology Law Quarterly, v. 36. Research Paper n. 2009-36. Maryland Legal Studies and Vermont Law School Research Paper n. 09-09. 15 out. 2009.

27 BECK, Ulrich. Sociedade de risco: rumo a uma outra modernidade. São Paulo: Editora 34, 2011.

28 LEFF, Enrique. Discursos sustentáveis. Tradução Silvana Cobucci Leite. São Paulo: Cortez, 2010.

29 HEY, Ellen. Global Environmental Law. 22 nov. 2009. Disponível em: <https://ssrn.com/abstract=1511188>. 
como critério de justificativa da participação social para a construção do direito ambiental global. A segunda parte do artigo define os limites da participação social para a construção do direito ambiental global, definindo limites endógenos e exógenos à participação social. Importante esclarecer que, mesmo existindo limites à participação social, isso não significa que esta não tenha utilidade na construção do direito ambiental global. Afinal, são os limites que definem o verdadeiro escopo da influência da participação social em relação à construção bottom-up do direito ambiental global, dando real contorno a essa participação.

\section{A participação social COMO CoAdjuVANTE DE UMA CONSTRUÇÃO BOTTOM-UP DO DIREITO AMBIENTAL GLOBAL}

A participação social pode contribuir para a definição de um direito ambiental global, principalmente quando pautado na atuação das partes interessadas e diretamente envolvidas em significativos impactos socioambientais, garantindo, assim, uma atuação coadjuvante dessa participação ${ }^{30}$ em relação à construção bottom-up do direito ambiental global.

A participação social das comunidades possui diversas vantagens para empresas e Estados ${ }^{31}$, das quais destacam-se: conformidade com as normas internacionais de RSE; antecipação das reações das pessoas afetadas pela implementação de um negócio; pacificação dos conflitos sociais que podem afetar a imagem comercial da empresa; redução dos riscos ambientais, financeiros e trabalhistas; prevenção de processos judiciais; a confiança dos investidores, e maior credibilidade e reputa-

30 A expressão coadjuvante da participação na construção do direito ambiental global está compreendida na atuação auxiliar da participação social para essa construção. Como se sabe, o coadjuvante, termo emprestado das artes cênicas, atua como um reforço aos protagonistas, garantindo o sucesso deste último. Assim também é a atuação da participação social em relação ao direito ambiental, pois ela busca reforçar e garantir o sucesso na construção de esse direito de forma global.

31 Sobre essa questão, Ziero (2016, p. 91) aponta para a importância do processo participativo realizado por meio do diálogo de diversos atores sociais "que estejam relacionados com tal cenário, por exemplo, produtores de soja, trabalhadores, sindicatos e representantes do Ministério Público do Trabalho, visando construir uma solução coletiva e sensível as particularidades do cenário no qual incide tal conflito normativo". ção para Estados e empresas ${ }^{32}$.

Assim, a participação social possui significativa utilidade na construção bottom-up do direito ambiental global, caracterizada por critérios (2.1) e instrumentos (2.2). Nesse panorama, é conveniente considerar que o acesso à informação representa uma condição para existência dessa participação social em relação à construção do direito ambiental global (2.1.1), sendo a vulnerabilidade uma justificativa para a existência dessa participação social (2.1.2); que tem a audiência pública como instrumento viável de participação social das comunidades locais (2.2).

\subsection{Critérios de utilidade da participação social para a construção bottom-up do direito ambiental global}

O acesso à informação (2.1.1) e a vulnerabilidade (2.1.2) são critérios (condição e justificativa, respectivamente) que demonstram a utilidade da participação social para a construção bottom-up do direito ambiental global. Ou seja, caracterizando a atuação coadjuvante da participação social em relação à construção de um direito ambiental global com atuação dos ambientes locais para gerar impactos em todo o mundo. Cabe ressaltar que esses critérios não definem os meios para essa atuação coadjuvante da participação social, para tanto, são necessários certos instrumentos, que serão apontados no item 2.2 deste trabalho.

\subsubsection{O acesso à informação como condição da participação social para a construção do direito ambiental global}

Como visto, a participação social é considerada gênero do qual possui várias espécies ${ }^{33}$. Ao analisar referidas espécies, observa-se que um dos principais elementos para a definição da participação social está na representação do princípio do democrático, existente no Direito Ambiental, que assegura aos cidadãos o direito de participar das discussões para a defesa do meio ambiente e

32 MARTIN-CHENUT, Kathia; PERRUSO, Camila; VARISON, Leandro. La diffcicile réparation des rapports sociaux. In: MARTINCHENUT, Kathia; QUENAUDON, René de. La RSE saisie par le droit: perspective interne et internationale. A. Pedone, 2016, p. 397416. 33 Participação popular; participação da sociedade civil organizada; participação dos Stakeholders (denunciantes; vítimas e acionistas). 
elaboração das políticas públicas ambientais ${ }^{34}$. Importante destacar que, para assegurar a realização do princípio do democrático, e, com isso, a participação social, é necessário que todos as partes vinculadas ao processo (neste artigo limitada a construção do direito ambiental global) devem ter assegurado o acesso às informações existentes sobre os fatos e condições necessários as tomadas de decisão.

Assim, o acesso às informações representa condição para a existência da participação social, pois, sem as informações reais dos possíveis danos que podem ser causados, torna-se impossível existir um direito ambiental global. Até porque a participação social pode auxiliar, direta e indiretamente, a identificação de possíveis impactos ambientais, por estarem (as partes interessadas) vinculadas às consequências dos danos ambientais. Portanto, o acesso à informação cria condições para que essa participação social exista e, assim, contribua com a construção do direito ambiental global.

Com a realização da Conferência Rio 92, o acesso adequado à informação passou a fazer parte das discussões ambientais, estando diretamente atrelada à questão da participação social das comunidades afetas por impactos significativos ${ }^{35}$. O acesso à informação depreende da possibilidade de saber sobre produtos e atividades realizadas por Estados e empresa (ditas atividades perigosas) como na possibilidade de participar do processo de decisão acerca da viabilidade ou não os empreendimentos com significativo impacto ambiental. O acesso à informação contribui para a estimulação da conscientização crítica da população, o que fomenta e assegura a participação desta na atuação juntamente a mecanismos judiciais e administrativos para a compensação e reparação de danos ambientais ${ }^{36}$. Observa-se que o acesso à informação é assegurando tanto na qualidade da informação dada como no modo como esta chegará às partes interessadas. Assim, cabe à parte interessada a escolha dos meios adequados para receberem tais informações e não aos entes que detêm a informação (a Convenção

34 ANTUNES, Paulo de Bessa. Direito Ambiental. 17 ed. amplamente reformulada. Editora Lumen Juris: Rio de Janeiro, 2015.

35 Tal fato pode ser comprovado pelo número de diplomas legais estabelecidos durante a Conferência e que apresentam em seu texto a garantia do acesso à informação e consulta pública, como Declaração do Rio (1992); Convenção sobre Efeitos Transfronteiriços de Acidentes Industriais (1992) e a Convenção Quadro das Nações Unidas sobre Mudança do Clima (1992).

36 Conforme dispõe o Princípio 10 da Declaração do Rio sobre Meio Ambiente e Desenvolvimento. sobre Efeitos Transfronteiriços de Acidentes Industriais de 1992 define esses detentores de informações como Parte de origem). Tanto as Partes afetadas como as Partes de origem (incluem todas as partes interessadas, garantindo a participação social - gênero), com o acesso à informação pertinentes, são capazes de participar dos processos, apresentar suas opiniões e preocupações em relação às decisões para decisões que, efetivamente, garantam a prevenção de possíveis impactos ambientais ${ }^{37}$ e a precaução de impactos ainda não definidos, como o caso da previsão estabelecida pela Convenção Quadro das Nações Unidas sobre Mudança do Clima (1992) ${ }^{38}$.

Em relação à qualidade da informação disponibilizada à população, os Princípios das Nações Unidas sobre Empresas e os Direitos Humanos (2011) ${ }^{39}$, tanto em relação às medidas adotadas para os impactos aos direitos humanos, como para a garantia de eficácia de mecanis$\operatorname{mos}^{40}$, as informações devem ser suficientes e assegurarem a equidade e transparência. Sobre esse aspecto, o Relatório de Desenvolvimento Humano da ONU de $2014^{41}$ também aponta que o acesso à informação aumento a consciência da opinião pública, garantindo, assim, o reconhecimento deste como condição para a utilidade da participação social no direito ambiental global. O Relatório aponta, inclusive, que os governos devem assegurar informações precisas sobre as vulnerabilidades dos indivíduos e acompanhar os efeitos das in-

37 Art. $9^{\circ}$ da Convenção sobre Efeitos Transfronteiriços de Acidentes Industriais (1992). Disponível em: < https://dre.pt/application/file/541296>.

38 Que define em seu art. $6^{\circ}$ que as Partes devem, ao cumprirem suas obrigações garantir o "ii) o acesso público a informações sobre a mudança do clima e seus efeitos; e iii) a participação pública no tratamento da mudança do clima e de seus efeitos e na concepção de medidas de resposta adequadas". Disponível em: <http://www.onu. org.br/rio20/img/2012/01/convencao_clima.pdf>.

39 ONU. Assembleia General das Nações Unidas. Rapport $\boldsymbol{d} \boldsymbol{u}$ Représentant spécial du Secrétaire général chargé de la question des droits de l'homme et des sociétés transnationales et autres entreprises, John Ruggie. Principes directeurs relatifs aux entreprises et aux droits de l'homme: mise en cuvre du cadre de référence 〈protéger, respecter et réparer» des Nations Unies. 21 mar. 2011.

40 Neste aspecto, a participação social também poderá contribuir para a criação de mecanismos de informação, conforme previsão descrita no art. 12, 2 do Protocolo de Nagoia no Âmbito da Convenção da Diversidade Biológica. 29 out. 2010. Disponível em: $<$ http://portal.iphan.gov.br/uploads/ckfinder/arquivos/Protocolo_de_nagoia.pdf $>$.

41 PNUD. Programa das Nações Unidas para o Desenvolvimento. Relatório do Desenvolvimento Humano 2014 - Sustentar o Progresso Humano: Reduzir as Vulnerabilidades e Reforçar a Resilência. Disponível em: <http://hdr.undp.org/sites/default/files/ hdr2014_pt_web.pdf>. 
tervenções políticas, o que garante a realização de uma participação direta por parte dos cidadãos.

Assim, diversos diplomas normativos elaborados durante a Conferência Rio 92 inter-relacionaram o acesso à informação à participação social definindo que: trata-se da garantia de conhecimento de informações com a qualidade necessárias para estimular a conscientização e fomenta/assegura a apresentação das opiniões e preocupações das partes interessadas em relação à prevenção e precaução de impactos ambientais. Como se pode observar, o acesso à informação cria condições para que a participação social possa repercutir seus efeitos na estruturação do direito ambiental global. Afinal, as sociedades, ao terem acesso às informações, podem realizar atuações conscientes e críticas para a proteção ambiental, objetivo maior do direito ambiental, passando, assim, a compor o quadro de agentes que constroem esse direito global.

A legislação brasileira, também, aponta para o mesmo sentido, ao descrever que o acesso à informação é condição para a garantia da participação social. Tal questão está prevista em diversas normas e regulamentos que descrevem que a sociedade deve ter as informações necessárias para a sua efetiva participação nos processos que afetem o meio ambiente ${ }^{42}$. Mesmo porque, definem mecanismos para garantir o acesso às informações e a participação da sociedade, como: o acesso ao Relatório de Impacto Ambiental (RIMA), a documentos e informações produzidos e a participação em audiências públicas para discussão das informações que tiveram acesso ${ }^{43445}$. Esse conjunto de mecanismos e procedimentos que garantem o acesso à informação e, com isso, a participação social em relação às questões

42 Resolução Conama 01/86; Lei no 8.666/1993 (institui normas para licitações e contratos da Administração Pública); Lei n. ${ }^{\circ} 10.257 / 2001$ (estabelece diretrizes gerais da política urbana); Resolução no 25/2005 (Regula o Estatuto das Cidades); Lei n ${ }^{\circ}$ 12.305/2010 (Institui a Política Nacional de Resíduos Sólidos) e Decreto $n^{\circ}$ 8.243/2014 (institui a Política Nacional de Participação Social - PNPS).

43 CONAMA. Resolução CONAMA n ${ }^{\circ}$ 001, de 23 de janeiro de 1986. D.O.U. 17 fev. 1986. Disponível em: <http://www.mma.gov. $\mathrm{br} /$ port/conama/res/res86/res0186.html $>$.

44 BRASIL. Lei n. ${ }^{\circ} 10.257$, de 10 de julho de 2001. Regulamenta os arts. 182 e 183 da Constituição Federal, estabelece diretrizes gerais da política urbana e dá outras providências. Planalto. Disponível em: <http://www.planalto.gov.br/ccivil_03/leis/LEIS_2001/ L10257.htm>.

45 Art. 39 da Lei $n^{\circ}$ 8.666, de 21 de junho de 1993 e art. $8^{\circ}$ e $9^{\circ}$ da Resolução no 25, de 18 de março de 2005 que regula o Estatuto das Cidades. ambientais é definido como controle social ${ }^{4647}$, realizado pelas populações interessadas, o que representa a atuação bottom-up da participação social para a construção do direito ambiental global. Por fim, a legislação brasileira reconhece que a participação social é direito do cidadão e expressão de autonomia, garantindo, nas diretrizes gerais do Decreto $n^{\circ} 8.243 / 2014$, que institui a Política Nacional de Participação Social - PNPS ${ }^{48}$, a necessidade de mecanismos e instancias democráticas complementares, transversais e integradas para a transparência e o controle social nas ações públicas, que representa o direito ao acesso à informação como condição dessa participação social. Mesmo porque, existindo o acesso à informação, criam-se possibilidades para que as partes interessas realmente possam influenciar nas tomadas de decisão e assim, realizar ações bottom-up para a construção do direito ambiental global.

Todas as previsões trazidas nas normas brasileiras e internacionais e destacadas acima são confirmadas por diversas decisões judiciais nacional e internacional. Principalmente quanto ao reconhecimento de uma maior atuação das partes interessadas quando existe acesso às informações ${ }^{49}$. Até porque a ausência de acesso à informação acaba gerando problemas às partes interessas e estas passam a judicializar demandas para esse $\mathrm{fim}^{50}$. Inclusive, existe o reconhecimento pelos julgados de que a existência de garantias de acesso às informações pelas leis proporciona um maior engajamento e uma participação mais ativa no processo de consulta pública ${ }^{51}$.

46 BRASIL. Decreto n. ${ }^{\circ}$ 8.243, de 23 de maio de 2014. Institui a Política Nacional de Participação Social - PNPS e o Sistema Nacional de Participação Social - SNPS, e dá outras providências. Planalto. Disponível em: < http://www.planalto.gov.br/ccivil_03/_Ato20112014/2014/Decreto/D8243.htm>.

47 BRASIL. Lei $\mathrm{n}^{\circ}$ 12.305, de 2 de agosto de 2010. Institui a Política Nacional de Resíduos Sólidos; altera a Lei no 9.605, de 12 de fevereiro de 1998; e dá outras providências. Planalto. Disponível em: < http://www.planalto.gov.br/ccivil_03/_ato2007-2010/2010/ lei/112305.htm>.

48 BRASIL. Decreto n. ${ }^{\circ}$ 8.243, de 23 de maio de 2014. Institui a Política Nacional de Participação Social - PNPS e o Sistema Nacional de Participação Social - SNPS, e dá outras providências. Planalto. Disponível em: <http://www.planalto.gov.br/ccivil_03/_Ato20112014/2014/Decreto/D8243.htm>.

49 Como ocorrido nos casos Sawhoyamaxa Vs. Paraguai; Claude Reyes e outros Vs. Chile e no Agrado de Instrumento n. ${ }^{\circ}$ 00286189620144010000. Decisão: 20/02/2017 do Tribunal Regional Federal da $1^{a}$ Região (TRF1).

50 Como ocorrido nos casos Claude Reyes e outros Vs. Chile. 51 CorteIDH. Corte Interamericana de Direitos Humanos. Caso Comunidade Indígena Sawhoyamaxa Vs. Paraguai. Organização dos Estados Americanos (OEA). 29 mar. 2006. Disponível em: <http://www.corteidh.or.cr/docs/casos/articulos/se- 
Diversas decisões judiciais, também, confirmam a necessidade de definição de mecanismos para garantir o acesso das comunidades às informações ${ }^{52}$. Cabe registar que tal questão também foi considerada como um dos critérios para a solução amistosa de conflitos da Comissão Interamericana de Direitos Humanos durante o Informe n. ${ }^{\circ}$ 30/04 - Petição 4617/02 (Caso Mercedes Julia Huenteao Beroiza e outras Vs. Chile) em 11 de março de 2004. Nesse caso, os peticionários apresentaram pedido de medidas cautelares para evitar danos irreparáveis aos direitos das vítimas, quando da inundação de terras ocupadas pelas vítimas para construção de barragem. As partes manifestaram, formalmente, a sua intenção de buscar uma solução amistosa em 26 de fevereiro de 2003. Durante a audiência realizada, definiram, entre outras medidas, que, para promover o desenvolvimento e conservação ambiental no setor do Alto Bío Bío, deveriam ser acordados mecanismos para assegurar que as comunidades indígenas sejam mantidas informados e sejam ouvidos para o monitoramento e controle de obrigações ambientais do Projeto da Hidrelétrica Ralco.

Os julgados possuem o mesmo objetivo apresentado pela legislação, tanto em sede nacional como internacional. Deve ser garantido o acesso à plena informação dos interessados, inclusive da comunidade, para facilitar o controle social tanto administrativamente como judicialmente ${ }^{53}$. O que mais uma vez confirma o acesso à informação como condição para a existência de participação social em relação à prevenção de impactos ambientais, contribuindo, assim, para a construção do direito ambiental global.

O acesso à informação como condição de efetiva participação social também foi reconhecido ressentimento pelo Parecer Consultivo do Tribunal Internacional Monsanto ${ }^{54}$, é um "tribunal de opinião", extraordinário, criado pela sociedade civil para examinar, de

riec_146_esp2.pdf>.

52 Como no Informe de Admissibilidade n. ${ }^{\circ}$ 62/14 - Petição 1216-03 (Colonos de Quishque-Tapayrihua Vs. Peru da Comissão Interamericana de Direitos Humanos); REsp 769.753/SC, Rel. Ministro HERMAN BENJAMIN, SEGUNDA TURMA, julgado em 08/09/2009, DJe 10/06/2011; TJMG - Ap Cível/Reex Necessário 1.0223.12.026598-6/001, Relator(a): Des.(a) Armando Freire , $1^{\mathrm{a}}$ CÂMARA CÍVEL, julgamento em 21/03/2017, publicação da súmula em 31/03/2017.

53 REsp 769.753/SC, Rel. Ministro HERMAN BENJAMIN, SEGUNDA TURMA, julgado em 08/09/2009, DJe 10/06/2011.

54 TRIBUNAL MONSANTO. Tribunal Internacional Monsanto. Avis Consultatif. La Haye, 18 abr. 2017. p. 19. acordo com o processo judicial, as regras de direito aplicável a eventos ou situações altamente problemáticas. Preocupação afetam, diretamente, as pessoas ou grupos de pessoas. Tendo como objetivo alertar o público, as partes interessadas e os tomadores de decisão. Os resultados são compartilhados com as partes interessadas e são amplamente disseminados na comunidade nacional e internacional. No caso do Tribunal Monsanto, o Parecer Consultivo aponta para a capacidade da sociedade de engajar um diálogo civil a fim de encorajar uma política ambiental eficaz, colocando o acesso à informação como uma das questões cruciais para o debate e a efetiva participação social.

\subsubsection{A vulnerabilidade como justificativa da participação social para a construção do direito ambiental global}

Como visto no item 2.1.1, o acesso à informação é condição de efetivação da participação social para a construção do direito ambiental global, contudo, fica a dúvida em relação à necessidade dessa participação. Realmente é necessário existir uma participação social para que se construa o direito ambiental global? O direito ambiental global, como já descrito acima, é visto como sendo um conjunto de princípios, normas e sistemas regulatórios/jurídicos ambientais nacionais, internacionais e transnacionais que tem o objetivo de proteger o meio ambiente. Esse direito nasce da colaboração cada vez maior entre governos, organizações não governamentais $(\mathrm{ONG})$, empresas multinacionais e redes ambientais transnacionais que influenciam na legislação e na regulamentação ambiental ${ }^{55}$.

Pesquisa realizada com o objetivo de definir um conceito jurídico de comunidade ${ }^{56}$ constatou que a vulnerabilidade é vista como critério para a confirmação da existência de uma comunidade, presente tanto nos textos normativos, como em julgados, nacionais e internacionais. Em decorrência dessa pesquisa, o critério vulnerabilidade permaneceu em destaque, tendo em vista os casos práticos existentes ${ }^{57}$. Como visto, o critério

55 YANG, Tseming; PERCIVAL, Robert V. The Emergence of Global Environmental Law. Ecology Law Quarterly, v. 36. Research Paper n. 2009-36. Maryland Legal Studies and Vermont Law School Research Paper n. 09-09. 15 out. 2009.

56 MONEBHURRUN, Nitish et al. A definição jurídica da "comunidade". Revista de Direito Internacional, Brasília, v. 13, n. 3, 2016.

57 Devido à natureza e à situação de fragilidade com potencial 
da vulnerabilidade está presente nas comunidades, ou seja, segmento da população de um determinado país em "situação jurídica diferenciada e especial por sofrer historicamente de uma discriminação e de uma ameaça cultural ou mesmo física" ${ }^{58}$. Observa-se que a pluralidade de atores envolvidos contribui, diretamente, para a estruturação do direito ambiental global, assim, a atuação da sociedade reflete a importância da realização de participação social, tendo a vulnerabilidade como justificativa para essa participação. Assim, a caraterística vulnerável também foi estabelecida como critério que justifica a utilidade da participação social nas tomadas de decisão e, assim, refletindo na construção bottom-up do direito ambiental global.

Em relação à reanálise dos textos normativos e julgados, nacionais e internacionais, utilizados na pesquisa "Definição Jurídica da Comunidade", foi possível identificar que a vulnerabilidade garante um tratamento diferenciado e proteção jurídica especial ${ }^{59}$, que possibilita uma atuação mais ativa das partes em ações de proteção ambiental. Inclusive, o Relatório do Desenvolvimento Humano da ONU (2014) aponta que "as convenções e conferências mundiais anteriores aumentaram os direitos e a visibilidade de grupos limitados pela vulnerabilidade estrutural"6061. O mesmo Relatório aponta, ainda, que "os governos, ao estabelecerem relações estreitas com o público, podem obter informações precisas sobre as vulnerabilidades dos indivíduos e acompanhar os efeitos das intervenções políticas" ${ }^{2}$. Contribuindo para

ameaça e, ainda, em virtude da existência de um reconhecimento de situação jurídica diferenciada e especial aplicada a estas, conforme definido na pesquisa "A definição jurídica da "comunidade".

58 MONEBHURRUN, Nitish et al. A definição jurídica da "comunidade". Revista de Direito Internacional, Brasília, v. 13, n. 3, 2016, p. 457.

59 Conforme constatado na pesquisa já referenciada acima sobre a definição jurídica de comunidade.

60 PNUD. Programa das Nações Unidas para o Desenvolvimento. Relatório do Desenvolvimento Humano 2014 - Sustentar o Progresso Humano: Reduzir as Vulnerabilidades e Reforçar a Resilência. Disponível em: <http://hdr.undp.org/sites/default/files/ hdr2014_pt_web.pdf $>$.

61 Questões confirmadas nas Convenções n 169 da OIT sobre Povos Indígenas e Tribais; sobre a proteção das crianças (20/11/1989); sobre a eliminação de discriminação contra as mulheres (18/12/1979); América sobre os Direitos Humanos e na Declaração das Nações Unidas sobre os Direitos dos Povos Indígenas (art. 25).

62 PNUD. Programa das Nações Unidas para o Desenvolvimento. Relatório do Desenvolvimento Humano 2014 - Sustentar o Progresso Humano: Reduzir as Vulnerabilidades e Reforçar a Resilência. Disponível em: <http://hdr.undp.org/sites/default/files/ hdr2014_pt_web.pdf>. que a participação social garanta uma liberdade e capacitação ativa da comunidade para atuação/influência nas tomadas de decisões.

Na prática, a vulnerabilidade é verificada considerando as ameaças sofridas, das quais destacam-se: as ameaças à sobrevivência humana, quando envolve cuidados nutricionais, médicos e de saúde (i.) ${ }^{63}$, as ameaças ao bem-estar social, quando relacionado as características econômico e social (ii) ${ }^{64}$; as ameaças em virtude de situação especial, tendo como base o direito consuetudinário, razões históricas, valores e costumes da comunidade (iii) ${ }^{65}$; as ameaças pela ausência de conhecimento de medidas técnicas e científicas (iv) ${ }^{66}$, e, por fim, as ameaças derivadas a ausência de capacidade jurídica $(\mathrm{v})^{67}$ que proporcione encontrar uma solução definitiva. Assim, as comunidades são consideradas as partes vulneráveis na relação jurídica, tendo em vista as ameaças existentes em decorrência da ausência de conhecimentos diversos, tanto em relação aos recursos (técnicos e financeiros) das atividades impactantes como em relação à atuação para a identificação/recuperação de impactos ambientais que podem decorrer dessas atividades.

Ademais, o Relatório do Desenvolvimento Humano da ONU (2014) aponta que a participação social é uma resposta eficiente de atuação das comunidades em relação às situações de vulnerabilidade vividas, ou seja, as ameaças que influenciam a definição vulnerável das comunidades $^{68}$. Constatada a vulnerabilidade das partes interessadas, tendo em vista os aspectos descritos acima, verifica-se que essa vulnerabilidade representa pon-

63 Conforme observado no caso Xákmok Kásek Vs. Paraguai $(24 / 05 / 2010)$;

64 Constatado a existência nos casos Kichwa de Sarayuku Vs. Equador (27/06/2012); Mayagna (Sumo) Awas Tingni Vs. Nicarágua (31/08/2001) e Saramaka Vs. Suriname (28/11/2007); Processo n. ${ }^{\circ}$ 0015808-66.2009.4.01.4300 - AC 2009.43.00.007547-1 / TO; Apelação Cível. Relator Desembargador Federal Néviton Guedes - Órgão $5^{a}$ Turma. Publicação 30/07/2015 e DJF1 P. 1086 - Data Decisão 17/06/2015 e STJ - REsp 1.187 .097 - j. 16/4/2013 - julgado por Marco Aurélio Gastaldi Buzzi - DJe 25/4/2013.

65 Casos Kichwa de Sarayuku Vs. Equador (27/06/2012); Mayagna (Sumo) Awas Tingni Vs. Nicarágua (31/08/2001) e Saramaka Vs. Suriname $(28 / 11 / 2007)$.

66 Conforme observado nos casos Xákmok Kásek Vs. Paraguai (24/05/2010) e Saramaka Vs. Suriname (28/11/2007);

67 O caso Saramaka Vs. Suriname $(28 / 11 / 2007)$ aponta nesse sentido;

68 PNUD. Programa das Nações Unidas para o Desenvolvimento. Relatório do Desenvolvimento Humano 2014 - Sustentar o Progresso Humano: Reduzir as Vulnerabilidades e Reforçar a Resilência. Disponível em: <http://hdr.undp.org/sites/default/files/ hdr2014_pt_web.pdf>. 
to de justificativa para a existência de uma participação social em relação à construção do direito ambiental.

Portanto, a garantia da participação social das comunidades nas tomadas de decisão ambiental ${ }^{69}$ proporciona a constatação de futuros impactos garante que possam resultar em danos ao meio ambiente e a comunidade. Tal questão foi verificada no caso da Comunidade Mayagna (Sumo) Awas Tingni Vs. Nicarágua (31/08/2001) que previu a realização de arranjo contratual com a empresa exploradora do recuso natural em suas terras, levando em consideração a participação dos habitantes da região, tanto para a construção legislativa (processo de consulta do Anteprojeto de Lei de titulação da propriedade comunitária indígena) como para a discussão das formas de atuação da empresa. Em que pese a realização dessa garantia participativa, constatou-se, ao final, que houve demora injustificada dos processos perante os tribunais; a recusa dos recursos interpostos pela Comunidade, e o descumprimento da sentença que declarou inconstitucional a concessão ${ }^{70}$. Portanto, a utilidade da participação social para a construção bottom-up do direito ambiental global é justificada pela vulnerabilidade existente no cerne de definição das comunidades, como visto acima.

As empresas e os Estados, como atores fomentadores do direito ambiental, detêm, em sua relação, uma certa autonomia na atuação, contudo, a vulnerabilidade em que se encontram, na prática, justifica a atuação da participação social em relação à construção do direito ambiental global, garantindo a quem é vulnerável uma atuação real, mesmo que coadjuvante para a construção do direito ambiental.

As contribuições coadjuvantes da participação social para a construção do direito ambiental estão, portanto, atrelada a uma formação bottom-up, pois a partes interessadas, ao terem sua participação garantida na prática (em cada caso concreto), contribuirão para que os problemas locais e regionais tenham a devida atenção e soluções para que haja a preservação e recuperação do

69 Ponto reconhecido nos julgados: Caso Yakye Axa Vs. Paraguai (17/06/2005); Xákmok Kásek Vs. Paraguai (24/05/2010); Kichwa de Sarayuku Vs. Equador (27/06/2012); Mayagna (Sumo) Awas Tingni Vs. Nicarágua (31/08/2001) e Saramaka Vs. Suriname (28/11/2007);

70 CorteIDH. Corte Interamericana de Direitos Humanos. Caso da Comunidade Mayagna (Sumo) Awas Tingni Vs. Nicarágua. Organização dos Estados Americanos (OEA). 31 ago. 2001. Disponível em: <http://www.corteidh.or.cr/docs/casos/articulos/ Seriec_79_por.doc $>$. meio ambiente. Esses fatores contribuem, diretamente, para a construção do direito ambiental global em sua modalidade bottom- p $^{71}$.

\subsection{A audiência pública como instrumento viável de participação social para a construção bottom-up do direito ambiental global}

Como visto ao longo deste artigo, a utilidade da participação social em relação à construção do direito ambiental está atrelada à garantia do acesso à informação às partes interessadas (2.1.1), tendo em vista sua vulnerabilidade (2.1.2). Observa-se que esses dois critérios da utilidade da participação social somente serão garantidos se houverem instrumentos que viabilizem uma real participação social das comunidades na atuação do direito ambiental. Sabe-se que tanto as empresas como os governos possuem estratégias e recursos financeiros, tecnológicos e humanos para contribuir e apresentar seus pontos de vista para a construção do direito ambiental. Contudo, na maioria das vezes, estes (empresas e governos) não resguardam a participação social das comunidades nessa construção ${ }^{72}$. Existem diversos instrumentos capazes de estabelecer consulta pública às partes interessadas no âmbito internacional, a consulta pública está prevista na Convenção n. ${ }^{\circ} 169$ da Organização Internacional do Trabalho - OIT sobre Povos Indígenas e Tribais (1989) que define que os povos interessados terão a consulta garantida mediante instrumento apropriados para isso. Esses meios devem garantir a participação livre, devendo os Estados estabelecer e manter procedimentos de consulta (art. $6^{\circ} \mathrm{e}$ 15 da Convenção $\left.{ }^{73}\right)$. Nessa órbita, a Convenção sobre Biodiversidade Biológica (1992) ${ }^{74}$ define que as consultas aos grupos interessados estão atreladas à aprovação

71 YANG, Tseming; PERCIVAL, Robert V. The Emergence of Global Environmental Law. Ecology Law Quarterly, v. 36. Research Paper n. 2009-36. Maryland Legal Studies and Vermont Law School Research Paper n. 09-09. 15 out. 2009.

72 Muitas vezes realizado apenas como "protocolo" ou atendimento da legislação, sem real efetividade na garantia de acesso a população na construção de elementos fundantes do direito ambiental, como é o caso de realização de audiências públicas em locais de difícil acesso ou horário comercial para evitar efetiva participação social.

73 OIT. Conferência Geral da Organização Internacional do Trabalho. Convenção n. ${ }^{\circ} 169$ da OIT sobre povos indígenas e tribais. 7 de junho de 1989.

74 ONU. Organização das Nações Unidas. Convenção sobre Diversidade Biológica. Conferência das Nações Unidas sobre Meio Ambiente e Desenvolvimento. Rio de Janeiro, jun. 1992. 
e participação destes quanto aos aspectos relacionados às práticas que afetem a biodiversidade biológica. E, por fim, a Assembleia General das Nações Unidas definiu os Princípios das Nações Unidas sobre Empresas e os Direitos Humanos ${ }^{75}$, conhecidos como Princípios Orientadores sobre Empresas e Direitos Humanos John Ruggie, aponta a necessidade de consulta pública às partes interessadas para a identificação e avaliação de riscos pelas empresas (Princípio 18). Em sede normativa brasileira, as legislações apontam as consultas públicas como instrumento participativo para garantir a gestão democrática e participação social nos processos decisórios ${ }^{76}$.

Existem diversas maneiras de estruturar uma consulta pública e, para tanto, pode-se empregar diferentes ferramentas para conduzir o processo ${ }^{77}$. Em análise de julgados, foi constato que, no Brasil, dentre as ferramentas existentes para a consulta pública, a audiência pública representa a ferramenta mais recorrente nos tribunais superiores e estatuais ${ }^{78}$. Tal questão é confirmada pela doutrina que aponta que a audiência pública representa um dos formatos mais conhecidos de con-

75 ONU. Assembleia General das Nações Unidas. Rapport $d \boldsymbol{u}$ Représentant spécial du Secrétaire général chargé de la question des droits de l'homme et des sociétés transnationales et autres entreprises, John Ruggie. Principes directeurs relatifs aux entreprises et aux droits de l'homme: mise en couvre du cadre de référence 〈protéger, respecter et réparer》 des Nations Unies. 21 mar. 2011.

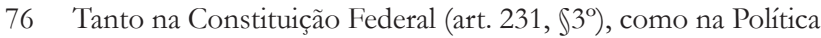
Urbana (Lei n. ${ }^{\circ} 10.257$, de 10 de julho de 2001); na Política Nacional de Resíduos Sólidos (Lei no 12.305, de 2 de agosto de 2010) e na Política Nacional de Participação Social (Decreto $n^{\circ} 8.243$, de 23 de maio de 2014);

77 A título de exemplo, as diversas ações ambientais, como: ação civil pública ambiental; improbidade administrativa ambiental; ação popular ambiental; mandado de segurança coletivo; além das possibilidades extrajudiciais como: acordos judiciais para monitoramento ambiental realizado pela empresa em locais de possíveis impactos socioambientais; inquérito civil ambiental; compromisso de ajustamento de conduta ambiental; audiências públicas; de participação popular da comunidade na elaboração legislativa de iniciativa popular ambiental; participação popular em Comitês e Conselhos de Meio Ambiente; participação da sociedade civil organizada (ONGs) na elaboração de projetos técnicos de grande impacto socioambiental, dentre outros.

78 A título de exemplo, tem-se: Agravo de Instrumento n. ${ }^{\circ}$ 00060213120174010000, Desembargador Federal Souza Prudente, TRF1, 14/03/2017; Agravo de Instrumento n. ${ }^{\circ}$ 00286189620144010000. Relator(a): Desembargador Federal Kassio Nunes Marques - TRF1 (24/02/2017); Agravo de InstrumentoCv 1.0210.11.002407-7/001 - TJMG; Ação Direta Inconstitucionalidade n. ${ }^{\circ}$ 1.0000.13.064955-1/000 - TJMG (21/11/2014) e Ação Direta Inconstitucionalidade n. ${ }^{\circ}$ 1.0000.00.254954-1/000 - TJMG (07/12/2001). sulta pública ${ }^{79}$. Diante desses pontos, o presente trabalho delimitou a análise para esse instrumento de consulta pública. Sendo constatado que a audiência pública representa instrumento viável para a realização dessa participação social na construção bottom-up do direito ambiental global.

Na legislação brasileira, a realização de audiências públicas está atrelada, diretamente, à participação da comunidade, sendo caracterizado como mecanismo de participação social "caráter presencial, consultivo, aberto a qualquer interessado, com a possibilidade de manifestação oral dos participantes, cujo objetivo é subsidiar decisões governamentais" ${ }^{\prime 0}$. No aspecto ambiental, a legislação define a obrigatoriedade de realização de audiências públicas visando assegurar aos interessados as informações sobre atividades empresariais e seus possíveis impactos ambientais ${ }^{81}$, garantindo a estes a possibilidade de dirimir dúvidas e apresentar críticas e sugestões a respeito ${ }^{82}$. Afinal, a democratização das tomadas de decisões, por meio da institucionalização da participação social das partes interessadas (stakeholders), contribuem para a prevenção, reparação e compensação de impactos negativos das ações empresariais ${ }^{83}$. Como se pode observar, a legislação ambiental brasileira garante, por meio da realização de audiências públicas, o acesso à informação, ponto já descrito neste artigo como condição para efetivação da participação social em relação à construção do direito ambiental. Ademais, por meio da legislação ambiental, houve a inauguração da prática de audiência públicas, as quais forma disseminadas em diversas outras finalidades ${ }^{84}$. Portanto, a audiência pública

79 SÁNCHEZ, Luis Enrique. Avaliação de impacto ambiental: conceitos e métodos. 2 ed. São Paulo: Oficina de Textos, 2013, p. 477.

80 Inciso VIII do art. $1^{\circ}$ do Decreto $\mathrm{n}^{\circ} 8.243$, de 23 de maio de 2014, que institui a Política Nacional de Participação Social - PNPS e o Sistema Nacional de Participação Social - SNPS, e dá outras providências. Disponível em: <http://www.planalto.gov.br/ccivil_03/_Ato2011-2014/2014/Decreto/D8243.htm>.

81 Tal questão está prevista no $₫ 2^{\circ}$ do art. 11 da Resolução Conama $^{\circ} 001$, de 23 de janeiro de 1986 e no art. 39 da Lei no 8.666, de 21 de junho de 1993, que regulamenta o art. 37, inciso XXI, da Constituição Federal, institui normas para licitações e contratos da Administração Pública e dá outras providências.

82 Art. $1^{\circ}$ da Resolução Conama n. ${ }^{\circ}$ 009/87, de 03 de dezembro de 1987. Disponível em: <http://www.mma.gov.br/port/conama/ res/res87/res0987.html $>$.

83 MARTIN-CHENUT, Kathia; PERRUSO, Camila; VARISON, Leandro. La difficile réparation des rapports sociaux. In: MARTINCHENUT, Kathia; QUENAUDON, René de. La RSE saisie par le droit: perspective interne et internationale. A. Pedone, 2016, p. 397416. 84 SÁNCHEZ, Luis Enrique. Avaliação de impacto ambien- 
também é mecanismo de participação social na realização de planos de gestão (como nos casos da elaboração de plano diretor ${ }^{8586}$ e Plano Nacional de Resíduos Sóli$\operatorname{dos}^{87}$ ), sendo observado, pelos pontos já apresentados, como instrumento de efetivação de participação social.

Para garantir essa efetivação da participação social, a Resolução Conama n. ${ }^{\circ}$ 009/87, de 03 de dezembro de 1987, aponta que as audiências deverão ser públicas, com definição de local e horário acessíveis e previamente anunciados em edital com ampla divulgação ${ }^{88}$. Diversas decisões judiciais no Brasil apontam no mesmo sentido da legislação ao reconhecer que as audiências públicas devem ser realizadas em locais de fácil acesso e devem contar com a participação de diversos segmentos da sociedade civil ${ }^{89}$.

Ademais, em razão da dificuldade de acesso das partes interessadas ao local, poderá ser realizada mais de uma audiência. Sendo dever dos órgãos ambientais a direção das audiências públicas para garantir o acesso real às informações e opiniões da população consultada, afinal, as informações colhidas em audiência servirão de base para que, juntamente aos dados disponibilizados pelo empreendedor nos estudos de avaliação de impacto ambiental (EIA/RIMA), possam embasar uma tomada de decisão coerente, visando menor impacto ambiental. Até porque, se o Estado não realizar audiência pública, a concessão da licença não terá validade ${ }^{90}$. Contudo, na prática, os Tribunais não adotam de pleno esse posicionamento, pois consideram desnecessária a realização de audiências públicas em diversos municí-

tal: conceitos e métodos. 2 ed. São Paulo: Oficina de Textos, 2013, p. 478.

85 BRASIL. Lei n. ${ }^{\circ} 10.257$, de 10 de julho de 2001. Regulamenta os arts. 182 e 183 da Constituição Federal, estabelece diretrizes gerais da política urbana e dá outras providências. Planalto. Disponível em: <http://www.planalto.gov.br/ccivil_03/leis/LEIS_2001/ L10257.htm>.

86 BRASIL. Resolução n 25, 18 mar. 2005. DOU Seção 1, Edição No 60 p.102. 30/03/2005. Disponível em: <http://planodiretor.mprs.mp.br/arquivos/resolucaoo25.pdf $>$.

87 BRASIL. Lei $\mathrm{n}^{\circ}$ 12.305, de 2 de agosto de 2010. Institui a Política Nacional de Resíduos Sólidos; altera a Lei no 9.605, de 12 de fevereiro de 1998; e dá outras providências. Planalto. Disponível em: < http://www.planalto.gov.br/ccivil_03/_ato2007-2010/2010/ lei/112305.htm>.

88 CONAMA. Resolução Conama n. ${ }^{\mathbf{0}} \mathbf{0 0 9} / \mathbf{8 7}$, de 03 de dezembro de 1987.

89 ACO 2868, Relator(a): Min. EDSON FACHIN, julgado em 03/08/2016, publicado em DJe-166 DIVULG 08/08/2016 PUBLIC 09/08/2016.

90 CONAMA. Resolução Conama n. ${ }^{\mathbf{0 0 9}} \mathbf{8 7}$, de 03 de dezembro de 1987. pios afetados por um único empreendimento, se existir amplo convite aos representantes das comunidades locais (associações, representantes de órgãos públicos, institutos e fundações que atuam na defesa do meio ambiente). Portanto, existe entendimento jurisprudencial de que, se houver convite realizado pelo empreendedor aos diversos representantes das comunidades, poderá ser reduzido o número de audiências públicas, pois demonstraria a ciência por parte desses segmentos ${ }^{91}$. Em que pese o entendimento jurisprudencial, sabe-se que a realização restrita de audiências públicas, quando atinge um número maior de municípios, pode representar uma restrição à consulta realizada aos interessados, pois, mesmo o convite realizado, fatores exógenos e endógenos, conforme apontado no item 3 deste artigo, podem prejudicar ainda mais a participação social.

Observa-se que, na maioria dos casos jurisprudenciais, a audiência pública é reconhecida como instrumento capaz de atribuir as informações necessárias às comunidades, fator que pode garantir a efetiva participação social nas tomadas de decisão ${ }^{923344596}$. Tal fato também foi verificado em audiência realizada pela Comissão Interamericana de Direitos Humanos. Durante a audiência pública (no caso Mercedes Julia Huenteao Beroiza e outras Vs. Chile 11/03/2004), houve a oitiva das partes, o que possibilitou a solução amistosa entre a empresa, Estado e comunidade ${ }^{97}$. Contudo, mesmo constatando a importância da audiência pública para a participação social em relação à prevenção de impactos ambiental, observa-se que não existe a efetivação dessa utilidade na prática regular (nem sede internacio-

91 ACO 2868, Relator(a): Min. EDSON FACHIN, julgado em 03/08/2016, publicado em DJe-166 DIVULG 08/08/2016 PUBLIC 09/08/2016.

92 AgRg na SLS 1.552/BA, Rel. Ministro Ari Pargendler, Corte Especial, julgado em 16/05/2012, DJe 06/06/2012.

93 AC 981, Relator(a): Min. Sepúlveda Pertence, julgado em 18/12/2006, publicado em DJ 01/02/2007 PP-00140

94 ACO 876 MC, Relator(a): Min. Sepúlveda Pertence, julgado em 18/12/2006, publicado em DJ 01/02/2007 PP-00148 RTJ VOL-00200-01 PP-00210.

95 TJMG. Ação Direta Inconstitucionalidaden. ${ }^{0}$ 1.0000.13.0649551/000, Relator(a): Des.(a) Márcia Milanez, Relator(a) para o acórdão: Des.(a) Wander Marotta , ÓRGÃO ESPECIAL, julgamento em 10/10/2014, publicação da súmula em 21/11/2014.

96 TJMG. Ação Direta Inconstitucionalidaden. ${ }^{\circ} 1.0000 .13 .063910-$ 7/000, Relator(a): Des.(a) Antônio Sérvulo , ÓRGÃO ESPECIAL, julgamento em 26/02/2014, publicação da súmula em 14/03/2014 97 CIDH. Comissão Interamericana de Direitos Humanos. Informe n 30/04. Petição 4617/02. Solução Amistosa Mercedes Julia Huenteao Beroiza y Otras Vs. Chile. Organização dos Estados Americanos (OEA). 11 mar. 2004. Disponível em: <http:// www.cidh.oas.org/annualrep/2004sp/Chile.4617.02.htm>. 
nal $^{98}$ e nem mesmo nos tribunais brasileiros $\left.{ }^{99100101}\right)$.

Outro ponto que deve ser considerado é o fato de que a audiência pública é vista como uma oportunidade para o debate, com participação de todos os segmentos da comunidade local ${ }^{102103}$, representando a participação social em sua maior atribuição, assim, contribuindo para a construção bottom-up do direito ambiental global.

Como visto na legislação brasileira, é dever do Estado efetivar a participação social por meio de audiências públicas, demonstrando, tanto na legislação como na prática, o reconhecimento destas como instrumento válido na efetivação da participação social na construção do direito ambiental global. Contudo, na prática, se observa que os no Brasil não se efetiva as audiências públicas conforme apontado pela legislação, existindo, como já descrito acima, diversos casos de afronta ao princípio, inclusive, a desnecessidade de realização de múltiplas audiências públicas se houver convite aos representantes das partes interessadas.

Observa-se que, nesses casos, sequer houve a verificação de ausência de participação da comunidade por desinteresse ou por desconhecimento, tendo em vista a necessidade de cumprimento, apenas, de meio formal de convite. Como visto, a efetiva participação social em sede de audiências pública possui dificuldades de ordem prática.

Ademais, cabe registrar que, ainda, existem outros critérios que agravam as dificuldades enfrentadas, para a efetivação da participação social em sede de audiência pública, como a disponibilidade das partes interessadas e seus representantes nos debates em audiências (devido ao tempo, vontade e falta de conhecimento). Afinal, nos casos de audiências pública para realização

98 Como ocorrido no caso Saramaka Vs. Suriname (28/11/2007), quando a Corte Interamericana de Direitos Humanos ouviu testemunhas e peritos para a coleta de informações sobre as atividades da empresa multinacional no território da comunidade.

99 RE 871744, Relator(a): Min. ROSA WEBER, julgado em 24/03/2015, publicado em PROCESSO ELETRÔNICO DJe-061 DIVULG 27/03/2015 PUBLIC 30/03/2015

100 ACO 876 MC, Relator(a): Min. Sepúlveda Pertence, julgado em 18/12/2006, publicado em DJ 01/02/2007 PP-00148 RTJ VOL-00200-01 PP-00210.

101 AC 981, Relator(a): Min. Sepúlveda Pertence, julgado em 18/12/2006, publicado em DJ 01/02/2007 PP-00140

102 ARE 978302, Relator(a): Min. MARCO AURÉLIO, julgado em 01/08/2016, publicado em PROCESSO ELETRÔNICO DJe163 DIVULG 03/08/2016 PUBLIC 04/08/2016

103 TJSC, Agravo de Instrumento n. 2011.031493-4, de Garopaba, rel. Des. Pedro Manoel Abreu, j. 04-06-2013. de EIA/RIMA em licenciamentos, para os debates em audiência, a parte interessada deve ter conhecimento dos dados contidos no RIMA, que muitas vezes são mal redigidos, além de que a falta de conhecimentos técnicos sobre o tema pode atrapalhar o entendimento em relação a atividade fruto do licenciamento ${ }^{104}$.

Portanto, observa-se que existe um reconhecimento legislativo e jurisprudencial das contribuições que as audiências públicas, como instrumento viável, para a construção bottom-up do direito ambiental global. Contudo, na prática, não existe uma efetiva articulação das ações neste sentido, o que limita a atuação da participação social ${ }^{105}$. É necessário, portanto, uma articulação ${ }^{106}$ com o objetivo de efetivar e otimizar a atuação desse instrumento, atribuindo na prática o reconhecimento já visto tanto nas normas como em diversas decisões judiciais e doutrina em relação às possibilidades na articulação para uma real participação social.

\section{Limites da Participação Social para a Construção do Direito Ambiental Global}

Como visto, a participação social possui significativa utilidade para a construção bottom-up do direito ambiental global (item 2). Essa participação pode contribuir para a definição de um direito ambiental pautado na atuação de todas as partes interessadas nos empreendimentos, principalmente naqueles com significativos impactos socioambientais, garantindo, assim, uma atuação coadjuvante dessa participação ${ }^{107}$ para a construção

104 SÁNCHEZ, Luis Enrique. Avaliação de impacto ambiental: conceitos e métodos. 2 ed. São Paulo: Oficina de Textos, 2013, p. 478.

105 Tais pontos serão explanados no item 3 deste trabalho que define os limites endógenos e exógenos para a participação social.

106 Essa articulação deve pautar-se, não somente, na atuação estatal para uma real participação social. sendo imprescindível o reconhecimento pelas empresas do papel e das contribuições da participação social no seu dia a dia. Ponto já explanado nos aspectos introdutórios desse item 2, quando MARTIN-CHENUT, Kathia; PERRUSO, Camila; VARISON, Leandro (2016) apontam as vantagens da participação social das comunidades para as empresas e os Estados, principalmente em relação à prevenção de impactos ambientais e danos às comunidades afetas e à pacificação de conflitos (sociais e judiciais) com essas comunidades.

107 A expressão coadjuvante da participação para a construção do direito ambiental global está compreendida na atuação auxiliar da participação social para essa construção. Como se sabe, o coadjuvante termo, emprestado das artes cênicas, atua como um reforço os protagonistas, garantindo o sucesso desse último. Assim também 
bottom-up do direito ambiental global. Contudo, verifica-se que na prática a participação social está limitada tanto à falta de recursos das comunidades locais para a identificação de impactos ambientais (limite endógeno) (3.1) como à ausência de uma real consulta prévia, livre e informada das comunidades (limite exógeno) (3.2).

\subsection{Um limite endógeno à participação social}

A falta de recursos das comunidades locais para a identificação de impactos ambientais

A participação social no direito ambiental representa a efetivação do princípio democrático ${ }^{108}$ e da participação comunitária ${ }^{109}$, questão já consolidada em diversas decisões judiciais e doutrina nacional e internacionais ${ }^{110}$. Assim, a existência de uma efetiva participação social não representa uma alteração dos instrumentos existentes ${ }^{111}$, mas sim um aprofundamento do exercício democrático, otimizando a atuação dos instrumentos e mecanismos existentes, como o caso das audiências públicas, ponto exposto na primeira parte deste artigo. Como visto acima, a participação social é útil para a construção bottom-up do direito ambiental global, pois, por meio da atuação das comunidades, é possível verificar todos os gargalos existência em nível local e identificar mecanismos e ações para atuação em nível global, realizando, assim, uma construção do direito ambiental global de

é a atuação da participação social em relação ao direito ambiental, pois ela busca reforçar e garantir o sucesso para a construção desse direito de forma global.

108 GUERRA, Sidney; GUERRA, Sérgio. Curso de Direito Ambiental. 2. ed. São Paulo: Atlas, 2014.

109 Esse princípio não representa exclusividade de aplicação nas questões ambientais, estando presente em todo o ordenamento jurídico brasileiro e internacional.

110 Como exemplo: AgRg na SLS 1.552/BA, Rel. Ministro Ari Pargendler, Corte Especial, julgado em 16/05/2012, DJe 06/06/2012. AC 981, Relator(a): Min. Sepúlveda Pertence, julgado em 18/12/2006, publicado em DJ 01/02/2007 PP-00140. ACO 876 MC, Relator(a): Min. Sepúlveda Pertence, julgado em 18/12/2006, publicado em DJ 01/02/2007 PP-00148 RTJ VOL00200-01 PP-00210. TJMG. Ação Direta Inconstitucionalidade n. ${ }^{\circ}$ 1.0000.13.064955-1/000, Relator(a): Des.(a) Márcia Milanez , Relator(a) para o acórdão: Des.(a) Wander Marotta , ÓRGÃO ESPECIAL, julgamento em 10/10/2014, publicação da súmula em 21/11/2014. TJMG. Ação Direta Inconstitucionalidade n. ${ }^{\circ}$ 1.0000.13.063910-7/000, Relator(a): Des.(a) Antônio Sérvulo , ÓRGÃO ESPECIAL, julgamento em 26/02/2014, publicação da súmula em 14/03/2014

111 LANDER, Edgardo. El Estado y las tensiones de la participación popular en Venezuela. OSAL, Buenos Aires: CLACSO, ano VIII, n, 22, septiembre, 2007. Disponível em: <http://bibliotecavirtual.clacso.org.ar/ar/libros/osal/osal22/D22Lander.pdf>. baixo para cima, retratando as realidades existentes em cada caso para construir um direito que contribua para a proteção global do ambiente. Ponto de extrema importância para a identificação e prevenção de impactos socioambientais.

Contudo, a falta de recursos (técnicos e financeiros) prejudica a real participação da comunidade em relação à identificação de impactos ambientais, e assim, limita as contribuições da comunidade para a construção de um direito ambiental global, definindo um limite endógeno da comunidade, em virtude de estar centrado em ações internas da mesma. Cabe registrar que os limites endógenos ${ }^{112}$ de uma comunidade acabam por limitar suas capacidades em atuar para a construção do direito ambiental, ou seja, a falta de recursos pela comunidade limita suas próprias capacidades de atuação. Assim, a falta de recursos técnicos e financeiros representa um limite endógeno à participação social, pois está expressa na ausência da capacidade interna da comunidade em realizar uma real participação social e, assim, contribuir para a construção bottom-up do direito ambiental global, conforme analisado na primeira parte deste artigo.

Tal questão é observada em diversos casos Corte Interamericana de Direitos Humanos (CorteIDH) da Organização dos Estados Americanos (OEA) ${ }^{113}$, observa-se que as comunidades ${ }^{114}$, ao buscarem seus direitos juntamente aos Estados Partes, não conseguiram seus objetivos, em virtude de ausência de recursos técnicos e financeiros. Afinal, provar seus direitos eram necessários aspectos intrínsecos ao conhecimento de especialistas, momento em que as comunidades buscaram a intervenção internacional para assegurar tal questão. Dentre os principais pontos encontrados, destaca-se que os Estados-Partes não proporcionaram às comunidades $\mathrm{O}$ acesso a recursos técnicos para garantir sua atuação. Inclusive foi verificada, em sentença proferida pela $\mathrm{CIDH}$, em 24 agosto de $2010^{115}$, a obrigatoriedade de o Estado

112 Endógeno representa o que se origina no interior de organismo ou sistema. Neste artigo a expressão representa o que se origina (ou seja, falta) no interior de uma organização/comunidade.

113 Comunidades Indígenas Xákmok Kásek Vs. Paraguai; Yakye Axa Vs. Paraguai; Sawhoyamaxa Vs. Paraguai; Mayagna (Sumo) Awas Tingni Vs. Nicarágua;

114 Nesses casos tendo como reflexo expressivo as comunidades indígenas.

115 CorteIDH. Corte Interamericana de Direitos Humanos. Caso Comunidade Indígena Xákmok Kásek Vs. Paraguai. Organização dos Estados Americanos (OEA). 24 ago. 2010. Disponível em: <http://www.corteidh.or.cr/docs/casos/articulos/ seriec_214_esp.pdf $>$. 
do Paraguai garantir, por meio de meios técnicos especializados, a participação de líderes comunitários na identificação específica do território e os seus limites. Efetivando, assim, uma participação social justa e com real impacto na construção do direito ambiental global. Outro ponto observado foram as constantes tentativas dos Estados Partes em realizar ações reiteradas para adiar a formação de provas em sede administrativa prévia aos julgados. Houve a solicitação por parte das Comunidades para a realização de uma inspeção ocular nas terras reivindicadas, que não foi realizado, gerando atrasos nos processos administrativos examinados ${ }^{116}$. Mais uma vez, observa-se que o empoderamento das comunidades por meio de recursos técnicos e financeiros poderá garantir a efetivação de um direito ambiental global, realizado bottom-up, ou seja, realizado com base nas comunidades e com garantia efetiva da proteção do meio ambiente.

Em julgados brasileiros, também existem apontamentos em relação às contribuições dos recursos técnicos e financeiros para efetivar a participação social das comunidades. Observa-se, contudo, que certos órgãos do governo brasileiro realizam a função de dar apoio técnico e financeiro às comunidades, como no caso do IBAMA e FUNAI. Como no caso da Apelação Cível n. ${ }^{\circ}$ 0000.96.81.920114-013900 - PA (Ação Civil Pública) contra a exploração de recursos energéticos em área indígena na UHE Belo Monte pelo descumprimento de condicionantes estipuladas na licença prévia $n^{\circ} 342 / 2010$. Nesse caso, a Comissão Interamericana de Direitos Humanos, com base no Parecer técnico 21/2009 da FUNAI, determinou ao Estado brasileiro que adote urgentes providências para proteger a vida, a saúde e integridade pessoal dos membros das comunidades indígenas; garanta a rápida finalização dos processos de regularização das terras ancestrais dos povos indígenas na bacia do Xingu e adote medidas efetivas para a proteção dos mencionados territórios ancestrais ante a apropriação ilegítima e ocupação por não indígenas, e frente à exploração ou ao deterioramento de seus recursos naturais. E, no caso do Agravo de Instrumento n. ${ }^{\circ} 00057554420174010000$, proferido pelo TRF1, em que a Associação Indígena Bayprã de Defesa do Povo Xikrin do O-Odja interpôs contra indeferimento dos pedidos de gratuidade da justiça e de antecipação da tutela, formulados em ação civil pública ajuizada contra o

116 Como ocorrido nos casos Yakye Axa Vs. Paraguai e Sawhoyamaxa vs. Paraguai
Instituto Brasileiro do Meio Ambiente e dos Recursos Naturais Renováveis (Ibama), objetivando o reconhecimento da nulidade das licenças ambientais concedidas pelo Ibama ao Empreendimento Ferro Carajás. Aliás. O IBAMA, com base no art. $4^{\circ}, \$ 1^{\circ}$ da Resolução CONAMA n. ${ }^{\circ} 237 / 1997$, realizou consulta a entidade especializada nos interesses indígenas durante os diversos atos do processo de licenciamento, garantindo, assim, que estes tivessem uma real participação no processo. Tem em vista o caráter de vulnerabilidade da comunidade frente à complexidade do processo licitatório.

Caso curioso foi observado em relação ao Habeas Corpus n. ${ }^{\circ}$ 0072.24.81.320114-010000/BA, em que o Ministério Público havia interposto Ação penal pelo suposto cometimento de crime de dano ambiental em desfavor do Reitor da Universidade do Estado da Bahia - UNEB, que teria colaborado a prática de dano mediante quando houve o fornecimento de projeto e apoio técnico para a construção da "Oca de Cultura Zabelê" nos limites do Parque Nacional do Descobrimento PND. Em sede de Habeas Corpus, ficou definida a falta de justa causa para ação penal, determinando o trancamento da ação penal. Contudo, o que se extrai desse caso como sendo mais importante é o fato de que muitas vezes o apoio técnico e financeiro realizado em favor das comunidades garantindo, assim, uma efetiva participação social para a construção do direito ambiental (neste caso integrado a questão da educação — também inclusa a educação ambiental), pode ser vista como uma afronta aos interesses de certas empresas e governos, fator que nos leva a refletir sobre como devem ser aceitas os apoios às comunidades. No caso em análise, não houve qualquer dano à Unidade de Conservação.

Até porque esse limite endógeno à participação social é observado também na legislação, pois tanto as normas internacionais como nacionais reconhecem a necessidade dos Estados e empresas auxiliarem as comunidades para acesso aos recursos técnicos e financeiros. Afinal, a participação social somente será efetivada se houver uma condição "relativa" de igualdade pelas partes interessadas em relação às informações quanto aos impactos socioambientais e quanto à reflexão sobre as responsabilidades frente ao direito ambiental.

\section{Desde a Agenda $21^{117}$ já se reconhecia a neces-}

117 ONU. Organização das Nações Unidas. Agenda 21. Conferência das Nações Unidas sobre Meio Ambiente e Desenvolvimento. Rio de Janeiro, jun. 1992. Disponível em: < http://www.onu.org.br/ 
sidade de estabelecer comitês intersetoriais nos planos político e técnico com ativa participação da comunidade interessada (formação de redes para compartilhamento de conhecimentos) ${ }^{118}$. Ademais, a mesma Agenda ainda acrescenta que os mecanismos de participação social somente poderão ser desenvolvidos de forma continuada se houver uma otimização "do uso adequado dos recursos financeiros e humanos da comunidade"119

A necessidade de acesso à recursos financeiros técnicos pelas comunidades também estão previstos na Declaração das Nações Unidas sobre os Direitos dos Povos Indígenas ${ }^{120}$. Para tanto, definiu a necessidade de cooperação, tanto financeira como de assistência técnica, para a definição dos mecanismos necessários à "participação dos povos indígenas em relação aos assuntos que lhes afetem"121.

Ademais, os Princípios das Nações Unidas sobre Empresas e os Direitos Humanos (2011) ${ }^{122}$ também definem a necessidade de assegurar as vítimas (estabelecidas no rol de Stakeholders ${ }^{123}$, aqui definida como espécie da participação social ${ }^{124}$ ), "acesso razoável às fontes de informação, ao assessoramento e aos conhecimentos especializados necessários para iniciar um processo de

rio20/img/2012/01/agenda21.pdf>.

118 Instituições científicas, culturais, religiosas, médicas, empresariais, sociais e outras instituições municipais (item 6.34 da Agenda 21); 119 Item i, alínea b, Capítulo 6 - Projeção e promoção das condições da saúde humana da Agenda 21.

120 ONU. Assembleia Geral das Nações Unidas. Declaração das Nações Unidas sobre os Direitos dos Povos Indígenas. 29 de junho de 2006. Disponível em: <http://www.un.org/esa/ socdev/unpfii/documents/DRIPS_pt.pdf>.

121 Art. 41 da Declaração das Nações Unidas sobre os Direitos dos Povos Indígenas. 29 de junho de 2006. Disponível em: <http:/ / www.un.org/esa/socdev/unpfii/documents/DRIPS_pt.pdf > .

122 Também denominados Princípios Orientadores sobre Empresas e Direitos Humanos - John Ruggie. Disponível em: <http:// www.ohchr.org/Documents/Issues/Business/A.HRC.17.31_ fr.pdf $>$.

123 A ISO 2600 define o termo stakeholders ao apontar no item 3.3, denominado "Características da responsabilidade social" que "uma parte interessada tem um ou mais interesses que podem ser afetados pelas decisões e atividades de uma organização. Esse interesse dá à parte interessada uma "participação" na organização, que cria uma relação com a organização. Essa relação não precisa ser formalizada ou mesmo reconhecida pela parte interessada ou pela organização. As partes interessadas podem também ser chamadas "stakeholders". Ao determinar quais interesses de partes interessadas serão reconhecidos, convém que a organização considere a legalidade desses interesses e sua consistência com as normas internacionais de comportamento" (grifo e destaque).

124 Como definido no item 2.1.1 deste artigo - Nota de rodapé 29. denúncia em condições de igualdade, com plena informação e respeito" 125 . Afinal, nos casos/litígios entre empresas e partes interessadas, existe uma desvantagem, pois as partes interessadas possuem menos acesso à informação e não possuem grandes recursos técnicos e financeiro para usá-lo. Importante refletir que, enquanto "este desequilíbrio não for corrigido, pode comprometer tanto o culminar de devido processo e a percepção que o público tem e torná-lo mais difícil de alcançar soluções duradouras" $" 126$.

A legislação brasileira também assegura a necessidade de recursos técnicos e financeiros para a garantia de uma real participação social. Em uma perspectiva geral, tal questão é analisada na criação de Conselhos, como observado pela Lei $\mathrm{n}^{\circ} 8.142$, de 28 de dezembro de 1990, que dispõe sobre a participação da comunidade na gestão do Sistema Único de Saúde (SUS) ${ }^{127}$ e no Decreto $\mathrm{n}^{\circ} 7.272$, de 25 de agosto de 2010. Regulamenta a Lei no 11.346, de 15 de setembro de 2006, que cria o Sistema Nacional de Segurança Alimentar e Nutricional - SISAN, com vistas a assegurar o direito humano à alimentação adequada ${ }^{128}$. Já em na perspectiva ambiental existem os Programas de Apoio à Conservação Ambiental e de Fomento às Atividades Produtivas Rurais, instituídos pela Lei no 12.512 , de 14 de outubro de $2011^{129}$. Essa norma, além da ambiental, social, edu-

125 Item "d" do Princípio 31 dos Princípios Orientadores sobre Empresas e Direitos Humanos - John Ruggie

126 CONECTAS. Princípios orientadores sobre empresas e direitos humanos: implementação dos parâmetros da ONU para proteger, respeitar e reparar. mar. 2012. p. 23. Disponível em: $<$ http://www.conectas.org/arquivos-site/Conectas_Princ $\%$ C3\%A DpiosOrientadoresRuggie_mar2012(1).pdf>.

127 BRASIL. Lei no 8.142, de 28 de dezembro de 1990. Dispõe sobre a participação da comunidade na gestão do Sistema Único de Saúde (SUS) e sobre as transferências intergovernamentais de recursos financeiros na área da saúde e dá outras providências. Planalto. Disponivel em: <http://www.planalto.gov.br/ccivil_03/leis/L8142.htm>. 128 BRASIL. Decreto no 7.272 , de 25 de agosto de 2010. Regulamenta a Lei no 11.346, de 15 de setembro de 2006, que cria o Sistema Nacional de Segurança Alimentar e Nutricional - SISAN com vistas a assegurar o direito humano à alimentação adequada, institui a Política Nacional de Segurança Alimentar e Nutricional - PNSAN, estabelece os parâmetros para a elaboração do Plano Nacional de Segurança Alimentar e Nutricional, e dá outras providências. Planalto. Disponível em: <http://www.planalto.gov.br/ccivil_03/_ ato2007-2010/2010/decreto/d7272.htm>.

129 BRASIL. Lei no 12.512, de 14 de outubro de 2011. Institui o Programa de Apoio à Conservação Ambiental e o Programa de Fomento às Atividades Produtivas Rurais; altera as Leis $n^{\circ}$ s 10.696, de 2 de julho de 2003, 10.836, de 9 de janeiro de 2004, e 11.326, de 24 de julho de 2006. Planalto. Disponível em: <http://www.planalto. gov.br/ccivil_03/_ato2011-2014/2011/lei/112512.htm>. 
cacional, técnica e profissional das comunidades, busca, ainda, incentivar a organização associativa e cooperativa de seus beneficiários para a conservação dos ecossistemas, entendida como sua manutenção e uso sustentável.

Observa-se que a necessidade de definir recursos técnicos e financeiros para a garantia de uma real participação social é observada tanto na legislação brasileira como internacional. Na legislação brasileira, essa participação está diretamente atrelada às políticas públicas. Essa última análise reflete o caráter político das normas brasileiras em relação à implementação de políticas com participação social, sempre atreladas aos órgãos ou às entidades públicas de controle dessa efetivação. Essa questão também é observada em julgados brasileiros, conforme apontado acima. Portanto, tanto a legislação brasileira como diversas decisões judiciais reconhecem a necessidade de existência de recursos técnicos e financeiros às comunidades para garantir a efetiva participação social em relação à proteção ambiental. Contudo, o Estado brasileiro sempre atrela o oferecimento desse apoio técnico e financeiro a um instituto ou órgão governamental, o que demonstra a atuação Estatal frente à vulnerabilidade das partes existentes em virtude das ameaças definidas pela ausência de conhecimento de medidas técnicas, científicas e jurídicos (conforme verificado no item 2.1.2 deste artigo). Essa atuação Estatal representa o cumprimento, mesmo não completo pelo Estado brasileiro, da responsabilidade deste em garantir a participação social das partes interessadas, conforme aponta as legislações internacionais e nacionais, já descritas neste trabalho.

Como visto até o presente momento, a ausência de recursos técnicos e financeiros às comunidades inviabiliza a efetivação da participação social. Contudo, casos concretos que garantiram recursos técnicos e financeiros às comunidades apontam para a garantia de uma maior participação social das comunidades ${ }^{130}$. Tendo como destaque o trabalho realizado pelo Fundo Mundial para a Natureza do World Wildlife Fund (WWF) na comunidade Awas Tingni na Nicarágua para assessoria. Nesse caso, a comunidade já havia iniciado um arranjo contratual com a empresa MADENSA, Maderas y Derivados de Nicaragua, para exploração madeireira que levasse em consideração a participação dos habitantes

130 Ponto observado no caso Mayagna (Sumo) Awas Tingni Vs. Nicarágua, em sentença proferida pela CIDH em 31 de agosto de 2001. da região. O Fundo Mundial para a Natureza encontrou, no caso da relação contratual, uma possibilidade de manejo florestal. O papel do Fundo Mundial para a Natureza consistiu em assegurar apoio à comunidade, com a formação de uma equipe técnica legal e o oferecimento de assessoria florestal, bem como assegurar que seria realizado um processo com a união de diferentes partes, com negociações realizadas por meio de um facilitador, o que resultou em um convênio tripartite (Comunidade, Estado e empresa). Observa-se, nesse caso, o apoio técnico e financeiro realizado pelo WWF resultou em uma real participação social e na proteção dos interesses da Comunidade, além de assegurar o manejo sustentável da floresta, ponto que liga o presente caso à construção bottom-up do direito ambiental global ${ }^{131}$. Outro caso de interesse trata-se da sentença proferida pela CIDH em 27 de junho de 2012 (Caso Povo Indígena Kichwa de Sarayaku Vs. Ecuador ${ }^{132}$ ) que relatou a existência de um Conselho de Direção composto por líderes tradicionais, autoridades comunitárias, ex-dirigentes, anciãos, sábio tradicional e grupos consultivos e comunidade técnica para tomadas de decisões em conjunto. Observa-se, mais uma vez, a presença de apoio técnico e financeiros às comunidades para assegurar a participação social destas nas decisões. Nesse caso tratava-se da ausência de consulta prévia à comunidade para a concessão de exploração de petróleo e exploração no território indígena. A gestão relativa à ausência de consulta será foco mais adiante deste trabalho. Mas observa-se que, somente após o apoio técnico realizado na comunidade, por meio do Conselho de Direção, esta passou a ter voz na declaração de suas vontades.

Tal questão também pode ser verificada nos casos em que houve ativa participação social dos interessados em relação à elaboração de legislação, como ocorrido com na Lei Francesa (LOI n 2017-399, de 27 de março de $2017^{133}$ ) que aponta o dever de vigilância

131 CorteIDH. Corte Interamericana de Direitos Humanos. Caso da Comunidade Mayagna (Sumo) Awas Tingni Vs. Nicarágua. Organização dos Estados Americanos (OEA). 31 ago. 2001. Disponível em: <http://www.corteidh.or.cr/docs/casos/articulos/Seriec_79_por.doc $>$.

132 CorteIDH. Corte Interamericana de Direitos Humanos. Povo Indígena Kichwa de Sarayaku Vs. Equador. Organização dos Estados Americanos (OEA). 27 jun. 2012. Disponível em: <http:// www.corteidh.or.cr/docs/casos/articulos/seriec_245_esp.pdf $>$. 133 FRANÇA. LOI n 2017-399, de 27 de março de 2017. Legifrance. Disponível em: <https://www.legifrance.gouv.fr/affichTexte.do?cidTexte $=$ JORFTEXT000034290626\&dateTexte $=\& c$ ategorieLien $=\mathrm{id}>$. 
das sociedades-mães e empresas doadoras. Referida lei buscou fortalecer a responsabilidade social empresarial (RSE) e contou com uma abordagem profundamente humanista, sendo construída como de forma coletiva com a colaboração de ONGs, sociedade civil, especialistas, políticos, ministros e sindicatos, o que representa a ativa participação das partes interessadas durante o processo de elaboração da lei. Observa-se que, para garantir a participação social em relação à elaboração dessa norma, houve a necessidade de colaboração de especialistas, garantindo, assim, os recursos financeiros e técnicos necessários para a participação da sociedade civil no processo democrático. Tal questão demonstra que, se houvesse mais recursos financeiros e técnicos disponíveis às comunidades, a atuação destas, para a construção do direito ambiental, teria maior representatividade e poderia contribuir para a prevenção de impactos socioambientais.

Cabe registar neste artigo, o papel fundamental do amicus curiae que garante, tanto na legislação como apontado no Código de Processo Civil brasileiro de $2015^{134} \mathrm{e}$ em diversas decisões judiciais (supracitadas), uma atuação concreta de apoio técnico às comunidades, permitindo, assim, uma real participação social e contribuindo para a prevenção de impactos socioambientais.

Verifica-se, assim, que, diante dos casos e legislações descritos acima ${ }^{135}$, existem comprovações de que as contribuições da participação social na construção bottom-up do direito ambiental global são válidas e, assim, podem contribuir para a prevenção de impactos socioambientais. Nesse sentido, essa participação social pode resultar na redução de conflitos (comunidades do entorno, Estados e empresas), quando realmente utilizarem os instrumentos disponíveis de forma adequada (item 2.2), em consonância com a garantia dos recursos técnicos e financeiros às comunidades locais, resultando em uma redução da vulnerabilidade existente na atuação das comunidades (item 2.1.2).

Essa questão é apontada, inclusive, pelo Relatório do

134 Código de Processo Civil 2015 - art. 138. "O juiz ou o relator, considerando a relevância da matéria, a especificidade do tema objeto da demanda ou a repercussão social da controvérsia, poderá, por decisão irrecorrível, de ofício ou a requerimento das partes ou de quem pretenda manifestar-se, solicitar ou admitir a participação de pessoa natural ou jurídica, órgão ou entidade especializada, com representatividade adequada, no prazo de 15 (quinze) dias de sua intimação". Disponível em: <http://www.planalto.gov.br/ccivil_03/_ ato2015-2018/2015/lei/113105.htm>.

135 Casos meramente exemplificativos e não exaustivos.
Desenvolvimento Humano da ONU (2014): “mesmo conferências a nível consultivo podem incentivar os Estados a tomar medidas com vista à redução da vulnerabilidade estrutural"136. Como ocorrido no caso do Tribunal Monsanto, já apontado no item 2.1.1 deste trabalho, que reconheceu o acesso à informação essencial para dar condições à efetiva participação social ${ }^{137}$, afinal, tem o objetivo de alertar o público, as partes interessadas e os tomadores de decisão sobre aspectos importantes da atuação empresarial, mesmo com seu caráter meramente consultivo. Assim, o caráter meramente consultivo não retira a atuação das partes interessadas para a construção do direito ambiental global, pois, ao atuarem em relação à proteção de "bens públicos globais, as partes se sentem "cidadãos do mundo - membros de uma comunidade global que beneficia de controle de capital, direitos laborais e direitos das mulheres" ${ }^{\text {"138. }}$.

\subsection{Um limite exógeno à participação social}

A ausência de real consulta prévia, livre e informada das comunidades interessadas

Os limites à participação social para a construção bottom-up do direito ambiental global também estão fundadas em aspectos exógenos às capacidades das comunidades, principalmente quanto à ausência de informações/ transparência por parte das empresas e Estados frente a proteção ambiental. Assim, a ausência de uma real consulta prévia, livre e informada das comunidades representa o limite exógeno dessa participação social. Afinal, inexistência de consulta (na prática ambiental) representa indício de ausência de participação social, o que leva à realização de um direito ambiental vazio do aspecto social essencial para sua construção. Nesse aspecto, a comunidade cada vez mais se envolve nos problemas ambientais, principalmente pelo amadurecimento da consciência da sociedade do dever democrático. Assim, o direito à consulta implica a necessidade de

136 PNUD. Programa das Nações Unidas para o Desenvolvimento. Relatório do Desenvolvimento Humano 2014 - Sustentar o Progresso Humano: Reduzir as Vulnerabilidades e Reforçar a Resilência. Disponível em: <http://hdr.undp.org/sites/default/files/ hdr2014_pt_web.pdf $>$.

137 TRIBUNAL MONSANTO. Tribunal Internacional Monsanto. Avis Consultatif. La Haye, 18 abr. 2017.

138 PNUD. Programa das Nações Unidas para o Desenvolvimento. Relatório do Desenvolvimento Humano 2014 - Sustentar o Progresso Humano: Reduzir as Vulnerabilidades e Reforçar a Resilência. 
acesso à informação às partes interessadas, que, como já exposto neste trabalho, representa meio de condição para a participação social na construção do direito ambiental global. Afinal, o primeiro passo está na possibilidade de ser informado, ouvido, e fazer as suas propostas, por todos os meios possíveis para chegar a um acordo através do diálogo intercultural ${ }^{139}$.

Ponto relevante é o fato de que as consultas à comunidade devem ser adequadas a cada perfil comunitário que será destinado, garantindo com isso uma real participação social das comunidades na forma de consultas. Sobre esse aspecto, já apontado no item 2.2, tanto a Convenção $n^{\circ}$ 169 sobre Povos Indígenas e Tribais da Organização Internacional do Trabalho - OIT ${ }^{140}$ como Convenção sobre Biodiversidade Biológica (1992) ${ }^{141}$ e os Princípios das Nações Unidas sobre Empresas e os Direitos Humanos ${ }^{142}$ apontam para a importância das consultas públicas. A Convenção no 169 da OIT, desde 1989 já apontava para a obrigatoriedade dos governos em realizar as consultas. Inclusive determina a necessidade de definição de procedimentos apropriados nos casos em que as populações são diretamente afetadas (medidas legislativas ou administrativas) $\left(\operatorname{art.} 6^{\circ}, 1\right.$, a). Nos termos do n ${ }^{\circ} 2$ do artigo $6^{\circ}$, a Convenção $n^{\circ} 169$ da OIT considera que "as consultas realizadas na aplicação desta Convenção deverão ser efetuadas com boa fé e de maneira apropriada às circunstâncias $[\ldots .$.$] ". Ademais, no \mathrm{n}^{\mathrm{o}} 1$, do art. $7^{\circ}$ : "os povos interessados deverão ter o direito de escolher suas, próprias prioridades no que diz respeito ao processo de desenvolvimento, na medida em que ele afete as suas vidas, crenças, instituições e bem-estar espiritual", além de "participar da formulação, aplicação e avaliação dos planos e programas de desenvolvimento nacional e regional suscetíveis de afetá-los diretamente". Outro ponto importante é o fato de que as consultas aos grupos interessados estão atreladas

139 IMAI, Shin. El Medioambiente, los Pueblos Indigenas y la Minería en Canadá. Indigenous Peoples in Canada and Peru: Free Prior Informed Consent. 25 nov. 2012. Osgoode CLPE Research Paper n. 46/2012. Disponível em: <https://ssrn.com/abstract $=2180658>$.

140 OIT. Conferência Geral da Organização Internacional do Trabalho. Convenção n. ${ }^{\circ} 169$ da OIT sobre povos indígenas e tribais. 7 de junho de 1989.

141 ONU. Organização das Nações Unidas. Convenção sobre Diversidade Biológica. Conferência das Nações Unidas sobre Meio Ambiente e Desenvolvimento. Rio de Janeiro, jun. 1992.

142 ONU. Assembleia General das Nações Unidas. Rapport du Représentant spécial du Secrétaire général chargé de la question des droits de l'homme et des sociétés transnationales et autres entreprises, John Ruggie. Principes directeurs relatifs aux entreprises et aux droits de l'homme: mise en cuvre du cadre de référence 〈protéger, respecter et réparer» des Nations Unies. 21 mar. 2011. à aprovação e à participação destes quanto aos aspectos relacionados às práticas que afetem a biodiversidade biológica. Tal fato é observado no art. $8^{\circ}$, “j” que aponta a necessidade de consulta às comunidades locais e populações indígenas com estilo de vida tradicionais ao definir que o Estado deve "incentivar sua mais ampla aplicação com a aprovação e a participação dos detentores desse conhecimento inovações e práticas". E, por fim, em se tratando de normas de aplicação internacional, ainda cabe destacar que conhecidos como Princípios Orientadores sobre Empresas e Direitos Humanos - John Ruggie, aponta, em seu Princípio 18, item "B" que a identificação e avaliação de riscos pelas empresas devem levar em consideração no processo "consultas substanciais com grupos potencialmente afetados e outras partes interessadas, em função do tamanho da empresa e da natureza e do contexto da operação". E, no Princípio 31, destaca que, para existir eficácia dos mecanismos não judiciais de denúncia, tanto estatais como não estatais, estes devem pautar-se na participação e no diálogo por meio de consultas aos grupos interessados. Portanto, o diálogo representa um dos requisitos necessários para a configuração das consultas eficazes. Em sede normativa brasileira, as legislações apontam as consultas públicas como instrumento participativo para garantir a gestão democrática e participação social nos processos decisórios ${ }^{143}$. Dentre os pontos de destaque, está o parágrafo único do art. 15 da Política Nacional de Resíduos Sólidos ${ }^{144}$ que aponta que o Plano Nacional deverá ser elaborado por meio de processo de mobilização e participação social, colocando as consultas públicas como instrumento dessa participação. Cabe registrar que este também é o entendimento da Política Nacional de Participação Social ${ }^{145}$ que a consulta pública como um dos mecanismos de participação social. Assim, a consulta pública além de ser um mecanismo participativo, possui caráter consultivo, aberto a qualquer interessado, devendo, ainda, apresentar os resultados da consulta com a indicação do procedimento adotado para alcança-los ${ }^{146}$.

143 Tanto na Constituição Federal (art. 231, §3º), como na Política Urbana (Lei n. ${ }^{\circ} 10.257$, de 10 de julho de 2001); na Política Nacional de Resíduos Sólidos (Lei n ${ }^{\circ} 12.305$, de 2 de agosto de 2010) e na Política Nacional de Participação Social (Decreto $n^{\circ} 8.243$, de 23 de maio de 2014);

144 BRASIL. Lei no 12.305, de 2 de agosto de 2010. Institui a Política Nacional de Resíduos Sólidos; altera a Lei no 9.605, de 12 de fevereiro de 1998; e dá outras providências. Planalto. Disponível em: <http:// www.planalto.gov.br/ccivil_03/_ato2007-2010/2010/lei/112305.htm>. 145 Art. $6^{\circ}$, inciso VIII da Política Nacional de Participação Social; 146 Inciso IX do art. $2^{\circ}$ da Política Nacional de Participação Social e art. 34 da Lei no 9.784, de 29 de janeiro de 1999, que regula o processo administrativo no âmbito da Administração Pública Federal; 
Com base em todo o exposto, que a consulta prévia, livre e informada representa um mecanismo participativo, de caráter consultivo, não obrigatório para as comunidades interessadas, devendo ser adequada a cada perfil comunitário e com procedimentos de apresentação dos resultados bem definidos para garantir uma real participação social das comunidades nos processos decisórios. Assim, a consulta garante a participação social, contudo, não se trata de uma permissão social, ou seja, ela possui cárter assessorial (ou seja, consultivo), não aferindo status de permissão.

Nesse sentido, parte da doutrina aponta que a consulta pública deveria ter caráter de permissão e não apenas um caráter consultivo. Esse é o entendimento de Kathia Martin-Chenut; Camila Perruso e Leandro Varison ${ }^{147}$ que apontam que a permissão social é uma ferramenta que ainda tem de demonstrar a sua eficácia, pois a permissão social deveria ser vista como um consentimento da comunidade e não como uma mera consulta. Ainda concluem que: l'obstacle majeur pour cela est sans doute le risque de son détournement par des entreprises qui, tout en continuant à dédaigner le respect des rapports sociaux, utilisent le permis social pour afficher une image socialement responsable. Diante do que aponta os autores, a mera consulta não representaria uma verdadeira participação social. Contudo, diante do que se pode analisar na aplicação prática da consulta prévia, livre e informada, sequer a consulta está sendo realizada conforme preconizam as legislações apontadas até aqui, o que dirá a consideração de uma permissão social, que significaria a opção de uma comunidade negociar medidas de compensação e reparação ao se posicionar frente à empresa causadora de impactos ambientais, condicionaria a comunidade a possibilidade de negar a presença da empresa e de proibir o desenvolvimento das atividades econômicas no território, o que a consulta não pode fazer dentro do que está preconizado nas legislações.

Nesse aspecto, vale considerar que a ideia de consulta prévia e participação social podem ser vistas como formas de promover o diálogo intercultural, porém, saber se o resultado desse diálogo pode significar real impacto nas tomadas de decisão, como cancelamento de um projeto $^{148}$ é ponto principal nesta indagação.

147 MARTIN-CHENUT, Kathia; PERRUSO, Camila; VARISON, Leandro. La difficile réparation des rapports sociaux. In: MARTINCHENUT, Kathia; QUENAUDON, René de. La RSE saisie par le droit: perspective interne et internationale. A. Pedone, 2016, p. 403-404.

148 IMAI, Shin. El Medioambiente, los Pueblos Indigenas y la Minería en Canadá. Indigenous Peoples in Canada and Peru: Free Prior Informed Consent. 25 nov. 2012. Osgoode CLPE Research Paper n. 46/2012. Disponível em: <https://ssrn.com/abstract $=2180658>$.
Na prática a falta de consulta prévia, livre e informada é recorrente, fator que limita a participação social para a promoção da proteção ambiental e para a construção bottom-up do direito ambiental global. A Corte Interamericana de Direitos Humanos (CorteIDH), em diversos $\operatorname{casos}^{149}$, já mencionados ${ }^{150151152153154}$, aponta para o afrontamento da consulta prévia, livre e informada. Nesses casos, a CIDH reconheceu que o Estado deve garantir a participação e consentimento informado das vítimas, expressa através de seus representantes e líderes. Além de ter a obrigação de tomar medidas legislativas, administrativas ou outras que se revelem necessário para fazer cumprir, dentro de um prazo razoável, o direito de consulta prévia dos povos e comunidades indígenas e tribais e mudar aquelas que impedir a seu livre e pleno exercício. Ponto importante é o fato de que a $\mathrm{CIDH}$, também, confirma que a consulta deve ser adequada a cada perfil comunitário, destacando sua própria forma de consulta e decisão, tendo em vista valores e costumes, presente nos julgados para assegurar a participação da própria comunidades. Ressalta-se que, no caso Sawhoyamaxa Vs. Paraguai ${ }^{155}$, o parecer emitido pelo Juiz Cançado Trindade apontou que, em relação à

149 Casos Povo Indígena Kichwa de Sarayaku Vs. Equador; Sawhoyamaxa Vs. Paraguai; Yakye Axa Vs. Paraguai; Mayagna (Sumo) Awas Tingni Vs. Nicarágua; Xákmok Kásek Vs. Paraguai; Mayas Del Distrito de Toledo Vs. Belice (Informe n. ${ }^{\circ}$ 40/04 12/10/2004).

150 CorteIDH. Corte Interamericana de Direitos Humanos. Caso Comunidade Indígena Sawhoyamaxa Vs. Paraguai. Organização dos Estados Americanos (OEA). 29 mar. 2006. Disponível em: <http://www.corteidh.or.cr/docs/casos/articulos/seriec_146_esp2.pdf $>$.

151 CorteIDH. Corte Interamericana de Direitos Humanos. Povo Indígena Kichwa de Sarayaku Vs. Equador. Organização dos Estados Americanos (OEA). 27 jun. 2012. Disponível em: <http:// www.corteidh.or.cr/docs/casos/articulos/seriec_245_esp.pdf $>$.

152 CorteIDH. Corte Interamericana de Direitos Humanos. Caso Comunidade indígena Yakye Axa Vs. Paraguai. Organização dos Estados Americanos (OEA). 17 jun. 2005. Disponível em: <http:// www.corteidh.or.cr/docs/casos/articulos/seriec_125_esp.pdf $>$.

153 CorteIDH. Corte Interamericana de Direitos Humanos. Caso da Comunidade Mayagna (Sumo) Awas Tingni Vs. Nicarágua. Organização dos Estados Americanos (OEA). 31 ago. 2001. Disponível em: < http://www.corteidh.or.cr/docs/casos/articulos/Seriec_79_por.doc $>$.

154 CorteIDH. Corte Interamericana de Direitos Humanos. Caso Comunidade Indígena Xákmok Kásek Vs. Paraguai. Organização dos Estados Americanos (OEA). 24 ago. 2010. Disponível em: <http://www.corteidh.or.cr/docs/casos/articulos/ seriec_214_esp.pdf>.

155 CorteIDH. Corte Interamericana de Direitos Humanos. Caso Comunidade Indígena Sawhoyamaxa Vs. Paraguai. Organização dos Estados Americanos (OEA). 29 mar. 2006. Disponível em: < http://www.corteidh.or.cr/docs/casos/articulos/seriec_146_esp2.pdf $>$. 
participação ativa nos processos de consulta, tal questão deve-se aos peticionários individuais tornaram-se ativamente envolvidos em todas as fases do processo perante o Tribunal.

Já no Brasil existem julgados que corroboram a necessidade de consulta prévia, livre e informada das comunidades tradicionais, representando, inclusive, justificativa para indeferimento de estudos, projetos e licenças de obras de significativo impacto ambiental, nos casos de ausência ${ }^{15157158}$. Também existem julgados que apontam que a consulta dos povos interessados deve ter o seu procedimento apropriado, adequado a cada perfil comunitário ${ }^{159}$, não devendo ficar restrita a consulta apenas aos indígenas, devendo ser feita em toda a comunidade do entorno $^{160}$. Contudo, o que se pode observar é o fato de que os julgados encontrados, em sua maioria, se restringem a casos de consulta prévia, livre e informada dos índios nos casos de aproveitamento dos recursos hídricos (potenciais hidroelétricos), tendo em vista a vedação constitucional para a realização de obras de significativo impacto nesses casos (art. 231, $₫ 3^{\circ}$ da Constituição Federal).

Outra questão que se deve considerar é o momento de realização da consulta prévia, em análise dos julgados, verificou-se que a consulta prévia deve ser feita após levantamento preliminar dos dados técnicos, tendo como objetivo discutir com as comunidades sobre questões de natureza socioambiental e culturais inerentes a obra. Contudo, não há impedimento que diferentes segmentos da sociedade sejam consultados durante os estudos de viabilidade do projeto $^{161}$.

156 BRASIL. Apelação Cível PA - Aproveitamento Hidroelétrico Belo Monte. Relator(a): Desembargadora Federal Selene Ma-

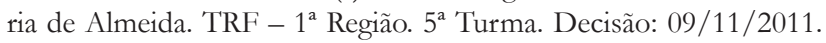
Publicação: e-djf1. 25/11/2011, p. 566.

157 BRASIL. Apelação Cível MT - Hidrovia Paraguai-Paraná. Porto de Morrinhos, na Região de Cáceres/MT. Relator(a): Desembargador Federal João Batista Moreira. TRF - $1^{\mathrm{a}}$ Região. $5^{\mathrm{a}}$ Turma. Decisão: 27/08/2007. Publicação: e-djf1. 05/10/2007, p. 60 158 BRASIL. REsp 1410732/RN. Rel. Ministro Herman Benjamin. STJ. $2^{\mathrm{a}}$ Truma. Decisão: 17/10/2013, Publicação: DJe 13/12/2016.

159 BRASIL. Embargos de Declaração na Apelação Cível PA - Usina Hidrelétrica de Belo Monte. Relator(a): Desembargador Federal Souza Prudente. TRF - $1^{a}$ Região. $5^{a}$ Turma. Decisão: 13/08/2012. Publicação: e-djf1. 27/08/2012, p. 316

160 BRASIL. Apelação Cível PA - Aproveitamento Hidroelétrico Belo Monte. Relator(a): Desembargadora Federal Selene Maria de Almeida. TRF - $1^{\text {a }}$ Região. $5^{\text {a }}$ Turma. Decisão: 09/11/2011. Publicação: e-djf1. 25/11/2011, p. 566.

161 BRASIL. Apelação Cível PA - Aproveitamento Hidroelétrico Belo Monte. Relator(a): Desembargadora Federal Selene Ma-
Assim, em caráter jurisprudencial, pode-se concluir que a consulta prévia, livre e informada não está sendo cumprida pelas empresas que geram impactos socioambientais ${ }^{162}$. Essa constatação nos leva a verificar certos problemas que derivam em uma análise da participação social dessas comunidades não consultadas. Pois, como já afirmado, a consulta é vista por muitos como uma garantia do princípio do democrático, o que seria, em uma análise prévia, a garantia de uma certa participação social. Portanto, é necessária a realização de uma verdadeira consulta às comunidades tradicionais para a efetivação da participação de grupos minoritários na tomada de decisões ambientais.

\section{Conclusões}

Ao longo deste artigo, foi possível verificar que a participação social está diretamente vinculada ao direito ambiental global, tanto em relação ao aspecto normativo como em relação ao entendimento de diversos julgados e na doutrina (presente em nível internacional e também no ordenamento interno brasileiro).

A utilidade da participação social para construção do direito ambiental global é reconhecida ao trazer contornos reais ao conceito ora construído, qual seja, a proteção do meio ambiente e o gerenciamento dos recursos naturais, através de critérios e instrumentos já existentes e aplicados na prática ambiental. Como critérios de utilidade na construção bottom-up do direito ambiental global, destacam-se a acesso à informação e a vulnerabilidade. $\mathrm{O}$ acesso à informação é visto, tantos nas normas como em diversas decisões judiciais e doutrina, como condição para existência dessa participação social na construção do direito ambiental global. Enquanto a vulnerabilidade é considerada meio de justificativa para a existência dessa participação social. Em relação aos ins-

ria de Almeida. TRF - $1^{\text {a }}$ Região. $5^{\text {a }}$ Turma. Decisão: 09/11/2011. Publicação: e-djf1. 25/11/2011, p. 566.

162 Constatado a existência nos casos Kichwa de Sarayuku Vs. Equador (27/06/2012); Colonos de Quishque-Tapayrihua Vs. Perú (24/07/2014); Agravo de Instrumento n. 0031.50.72.320144-010000 - AM. Relator(a): Desembargador Federal Ney Bello. TRF 1. $3^{\text {a }}$ Turma (09/06/2015); Apelação Cível n. ${ }^{\circ} 0005.89 .18 .120124-013600$ - MT. Relator(a) Desembargador Federal Souza Prudente. TRF 1. $5^{\text {a Turma (09/10/2013); Agravo n. }{ }^{\circ} 00060213120174010000 . \text { Rela- }}$ tor: Desembargador Federal Souza Prudente, TRF1 (14/03/2017) e Agravo de Instrumento n. ${ }^{\circ} 00057554420174010000$. Relator(a): Desembargador Federal Daniel Paes Ribeiro, TRF1 (16/02/2017). 
trumentos, a audiência pública é considerada, na maioria dos casos estudados (nacionais e internacionais), como instrumento mais aplicado e, assim, considerada viável para a participação social das comunidades locais, fator que vincula, mais uma vez, a participação social como fator útil à construção bottom-up do direito ambiental global.

Em que pese a existência de uma utilidade da participação social para a construção do direito ambiental global, essa atuação, no formato e modo como vem sendo aplicada, é limitada, em aspectos internos (a falta de recursos das comunidades locais para a identificação de impactos ambientais) e externos (a ausência de real consulta prévia, livre e informada das comunidades interessadas), conforme observado na prática nacional e internacional.

Portanto, conclui-se que a participação social é útil para a construção do direito ambiental global, realizando uma atuação bottom-up dessa construção, contudo, existe limites que devem ser considerados nesta análise, os quais não retiram o fulgor dessa atuação. E, por fim, cabe mencionar que referido tema é essencialmente novo, tanto em relação à criação do direito ambiental global, como em relação à atuação da participação social. Logo, evidencia-se a necessidade de ampliação desse tema em futuras pesquisas, principalmente em relação ao enfrentamento dos aspectos inerentes aos limites internos e externos da participação e em relação à definição de soluções para a redução desses limites, ampliando, assim, a atuação da participação social.

\section{REFERÊNCIAS}

ANDRADE, Priscila Pereira de. A emergência do direito transnacional ambiental. Revista de Direito Internacional, Brasília, v. 13, n. 3, 2016 p. 17-28.

ANTUNES, Paulo de Bessa. Direito Ambiental. 17 ed. amplamente reformulada. Editora Lumen Juris: Rio de Janeiro, 2015.

BARBOSA, Luiza Nogueira; MOSCHEN, Valesca Raizer Borges. O direito transnacional ("global law") e a crise de paradigma do estado-centrismo: é possível conceber uma ordem jurídica transnacional? Revista de Direito Internacional, Brasília, v. 13, n. 3, 2016, p. 145-158
BECK, Ulrich. Sociedade de risco: rumo a uma outra modernidade. São Paulo: Editora 34, 2011.

BOYD, William. Climate Change, Fragmentation, and the Challenges of Global Environmental Law: Elements of a PostCopenhagen Assemblage. University of Pennsylvania Journal of International Law, v. 32, n. 2, p. 457, 01 set. 2010. Disponível em: https://ssrn.com/abstract=1739123>.

BRASIL. Supremo Tribunal Federal. Ação Cautelar 981. Relator(a): Min. Sepúlveda Pertence, julgado em 18/12/2006, publicado em DJ 01/02/2007 PP-00140. DJe 06/06/2012.

BRASIL. Supremo Tribunal Federal. Ação Cautelar 981. Relator(a): Min. Sepúlveda Pertence, julgado em 18/12/2006, publicado em DJ 01/02/2007 PP-00140

BRASIL. Supremo Tribunal Federal. Ação Cautelar 981. Relator(a): Min. Sepúlveda Pertence, julgado em 18/12/2006, publicado em DJ 01/02/2007 PP-00140.

BRASIL. Supremo Tribunal Federal. Ação Cível Originária 876 MC. Relator(a): Min. Sepúlveda Pertence, julgado em 18/12/2006, publicado em DJ 01/02/2007 PP-00148 RTJ VOL-00200-01 PP-00210.

BRASIL. Apelação Cível MT - Hidrovia ParaguaiParaná. Porto de Morrinhos, na Região de Cáceres/MT. Relator(a): Desembargador Federal João Batista Moreira. TRF - $1^{\text {a }}$ Região. $5^{\text {a }}$ Turma. Decisão: 27/08/2007. Publicação: e-djf1. 05/10/2007.

BRASIL. Supremo Tribunal Federal. ACO 876 MCAgR, Relator(a): Min. MENEZES DIREITO, Tribunal Pleno, julgado em 19/12/2007, DJe-142 DIVULG 3107-2008 PUBLIC 01-08-2008 EMENT VOL-02326-01 PP-00044 RTJ VOL-00205-02 PP-00537.

BRASIL. Superior Tribunal de Justiça. REsp 769.753/SC, Rel. Ministro HERMAN BENJAMIN, SEGUNDA TURMA, julgado em 08/09/2009, DJe 10/06/2011.

BRASIL. Apelação Cível PA - Aproveitamento Hidroelétrico Belo Monte. Relator(a): Desembargadora Federal Selene Maria de Almeida. TRF - $1^{a}$ Região.

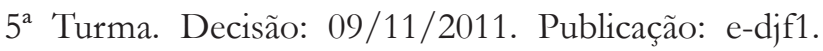
$25 / 11 / 2011$.

BRASIL. Supremo Tribunal Federal. Agravo Regimental na SLS 1.552/BA, Rel. Ministro Ari Pargendler, Corte Especial, julgado em 16/05/2012.

BRASIL. Supremo Tribunal Federal. Agravo Re- 
gimental na SLS 1.552/BA. Rel. Ministro Ari Pargendler, Corte Especial, julgado em 16/05/2012, DJe 06/06/2012.

BRASIL. Embargos de Declaração na Apelação Cível PA - Usina Hidrelétrica de Belo Monte. Relator(a): Desembargador Federal Souza Prudente. TRF - $1^{a}$ Região. $5^{a}$ Turma. Decisão: 13/08/2012. Publicação: e-djf1. 27/08/2012.

BRASIL. Superior Tribunal de Justiça. REsp 1187097/PR, Rel. Ministro MARCO BUZZI, QUARTA TURMA, julgado em 16/04/2013, DJe 25/04/2013.

BRASIL. AP - Apelação. n. ${ }^{\circ}$ 0005.89.18.120124013600. Relator(a): Desembargador Federal Souza Prudente. TRF - $1^{a}$ Região. $3^{\text {a }}$ Turma. Decisão: 09/10/2013.

BRASIL. Supremo Tribunal Federal. Recurso Extraordinário 871744. Relator(a): Min. ROSA WEBER, julgado em 24/03/2015, publicado em PROCESSO ELETRÔNICO DJe-061 DIVULG 27/03/2015 PUBLIC 30/03/2015

BRASIL. AI - Agravo de Instrumento. n. ${ }^{\circ}$ 00031.50.72.320144-010000. Relator(a): Desembargador Federal Ney Bello. TRF $-1^{a}$ Região. $3^{\text {a Turma. De- }}$ cisão: 09/06/2015.

BRASIL. APREENEC - Apelação/Remessa Necessária. n. ${ }^{\circ}$ 0015808-66.2009.4.01.4300. Relator(a): Desembargador Federal Néviton Guedes. TRF - $1^{a}$ Re-

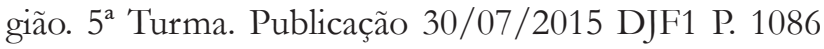
- Data Decisão 17/06/2015.

BRASIL. Supremo Tribunal Federal. Recurso Extraordinário 978302. Relator(a): Min. MARCO AURÉLIO, julgado em 01/08/2016, publicado em PROCESSO ELETRÔNICO DJe-163 DIVULG 03/08/2016 PUBLIC 04/08/2016

BRASIL. Supremo Tribunal Federal. Ação Cível Originária 2868. Relator(a): Min. EDSON FACHIN, julgado em 03/08/2016, publicado em DJe-166 DIVULG 08/08/2016 PUBLIC 09/08/2016.

BRASIL. REsp 1410732/RN. Rel. Ministro Herman Benjamin. STJ. $2^{a}$ Truma. Decisão: 17/10/2013, Publicação: DJe 13/12/2016.

BRASIL. AI - Agravo de Instrumento. n. ${ }^{\circ}$ 00057554420174010000. Relator(a): Desembargador Federal Daniel Paes Ribeiro. TRF - $1^{a}$ Região. $6^{a}$ Turma. Decisão: 16/02/2017.
BRASIL. AI - Agravo de Instrumento. n. ${ }^{\circ}$ 00286189620144010000. Relator(a): Desembargador Federal Kassio Nunes Marques. Tribunal Regional Federal - $1^{a}$ Região. 6a Turma. Decisão: 20/02/2017.

BRASIL. AI - Agravo de Instrumento. n. ${ }^{\circ}$ 00060213120174010000. Relator(a): Desembargador Federal Souza Prudente. TRF - $1^{a}$ Região. $5^{\text {a }}$ Turma. Decisão: 14/03/2017.

CIDH. Comissão Interamericana de Direitos Humanos. Informe n 30/04. Petição 4617/02. Solução Amistosa Mercedes Julia Huenteao Beroiza y Otras Vs. Chile. Organização dos Estados Americanos (OEA). 11 mar. 2004. Disponível em: < http://www.cidh.oas. org/annualrep/2004sp/Chile.4617.02.htm>.

CIDH. Comissão Interamericana de Direitos Humanos. Comunidades Indígenas Mayas do Distrito de Toledo Vs. Belize. Organização dos Estados Americanos (OEA). 12 out. 2004. Disponível em: <https://www. cidh.oas.org/annualrep/2004sp/Belize.12053.htm>.

CIDH. Comissão Interamericana de Direitos Humanos. Caso Colonos de Quishque-Tapayrihua Vs. Perú. Organização dos Estados Americanos (OEA). 24 jul. 2014. Disponível em: <http://www.oas.org/es/ cidh/decisiones/2014/PEAD1216-03ES.pdf>.

CONAMA. Resolução Conama n. ${ }^{\mathbf{0}} \mathbf{0 0 9 / 8 7}$, de 03 de dezembro de 1987. D.O.U. 05 set. 1990, Seção I, p. 12. Disponível em: <http://www.mma.gov.br/port/cona$\mathrm{ma} / \mathrm{res} / \mathrm{res} 87 / \mathrm{res} 0987 . \mathrm{html}>$.

CONAMA. Resolução $\mathbf{n}^{\circ}$ 237, de 19 de dezembro de 1997. Disponível em: <http://www.mma.gov.br/port/ conama/res/res97/res23797.html $>$.

CONAMA. Resolução CONAMA n ${ }^{\circ}$ 001, de 23 de janeiro de 1986. D.O.U. 17 fev. 1986. Disponível em: <http://www.mma.gov.br/port/conama/res/res86/ res0186.html>.

CONECTAS. Princípios orientadores sobre empresas e direitos humanos: implementação dos parâmetros da ONU para proteger, respeitar e reparar. mar. 2012. p. 23. Disponível em: <http://www.conectas. org/arquivos-site/Conectas_Princ\%C3\%ADpiosOrien tadoresRuggie_mar2012(1).pdf>.

CorteIDH. Corte Interamericana de Direitos Humanos. Caso da Comunidade Mayagna (Sumo) Awas Tingni Vs. Nicarágua. Organização dos Estados Americanos (OEA). 31 ago. 2001. Disponível em: 
$<$ http://www.corteidh.or.cr/docs/casos/articulos/Seriec_79_por.doc $>$.

CorteIDH. Corte Interamericana de Direitos Humanos. Caso Comunidade indígena Yakye Axa Vs. Paraguai. Organização dos Estados Americanos (OEA). 17 jun. 2005. Disponível em: <http://www.corteidh. or.cr/docs/casos/articulos/seriec_125_esp.pdf>.

CorteIDH. Corte Interamericana de Direitos Humanos. Caso Comunidade Indígena Sawhoyamaxa Vs. Paraguai. Organização dos Estados Americanos (OEA). 29 mar. 2006. Disponível em: <http://www.corteidh. or.cr/docs/casos/articulos/seriec_146_esp2.pdf>.

CorteIDH. Corte Interamericana de Direitos Humanos. Caso Claude Reyes e outros Vs. Chile. Organização dos Estados Americanos (OEA). 19 set. 2006. Disponível em: <http://www.corteidh.or.cr/docs/casos/articulos/seriec_151_esp.pdf $>$.

CorteIDH. Corte Interamericana de Direitos Humanos. Caso do Povo Saramaka Vs. Suriname. Organização dos Estados Americanos (OEA). 28 nov. 2007. Disponível em: < http://www.corteidh.or.cr/docs/casos/articulos/seriec_172_esp.pdf>.

CorteIDH. Corte Interamericana de Direitos Humanos. Caso Comunidade Indígena Xákmok Kásek Vs. Paraguai. Organização dos Estados Americanos (OEA). 24 ago. 2010. Disponível em: <http://www. corteidh.or.cr/docs/casos/articulos/seriec_214_esp. pdf $>$.

CorteIDH. Corte Interamericana de Direitos Humanos. Povo Indígena Kichwa de Sarayaku Vs. Equador. Organização dos Estados Americanos (OEA). 27 jun. 2012. Disponível em: <http://www.corteidh.or.cr/ docs/casos/articulos/seriec_245_esp.pdf $>$.

CZARNEZKI, Jason J.; LIN, Yanmei; FIELD, Cameron. Global Environmental Law: Food Safety \& China. 21 ago. 2012. Vermont Law School Research Paper n. 20-12. Disponível em: <https://ssrn.com/ abstract $=2133551$ or http://dx.doi.org/10.2139/ ssrn.2133551>.

DESLAURIERS, Jean-Pierre. A indução analítica. In: POUPART, Jean et al. A pesquisa qualitativa: enfoques epistemológicos e metodológicos. Trad. Ana Cristina Arantes Nasser. Petrópolis/RJ, Editora Vozes, 2014, p. 337-352.

GUERRA, Sidney; GUERRA, Sérgio. Curso de Direi- to Ambiental. 2. ed. São Paulo: Atlas, 2014.

HEY, Ellen. Global Environmental Law. 22 nov. 2009. Disponível em: <https://ssrn.com/abstract $=1511188>$.

IMAI, Shin. El Medioambiente, los Pueblos Indígenas y la Minería en Canadá. Indigenous Peoples in Canada and Peru: Free Prior Informed Consent. 25 nov. 2012. Osgoode CLPE Research Paper n. 46/2012. Disponível em: <https:// ssrn.com/abstract $=2180658>$.

KAUSHIK, Uma; MAHADEVAN, B. Strategic Sourcing: Trends and Emerging Issues for Research. 20 dez. 2011. In: IIM Bangalore Research Paper $\mathbf{n} .^{\mathbf{0}} 335$. Disponível em: <https://ssrn.com/abstract $=2121140$ or http://dx.doi.org/10.2139/ssrn.2121140>.

LEFF, Enrique. Discursos sustentáveis. Tradução Silvana Cobucci Leite. São Paulo: Cortez, 2010.

MARTIN-CHENUT, Kathia; PERRUSO, Camila; VARISON, Leandro. La difficile réparation des rapports sociaux. In: MARTIN-CHENUT, Kathia; QUENAUDON, René de. La RSE saisie par le droit: perspective interne et internationale. A. Pedone, 2016, p. 397-416.

MILARÉ, Édis. Direito do Ambiente: a gestão ambiental em foco - doutrina, jurisprudência, glossário. 9 ed. São Paulo: Editora Revista dos Tribunais, 2014.

MINAS GERAIS. Tribunal de Justiça do Estado de Minas Gerais. TJMG - Ação Direta Inconst. 1.0000.00.254954-1/000, Relator(a): Des.(a) Almeida Melo, CORTE SUPERIOR, julgamento em 14/11/2001, publicação da súmula em 07/12/2001).

MINAS GERAIS. Tribunal de Justiça do Estado de Minas Gerais. TJMG - Agravo de InstrumentoCv 1.0210.11.002407-7/001, Relator(a): Des.(a) Teresa Cristina da Cunha Peixoto, $8^{a}$ CÂMARA CÍVEL, julgamento em 06/10/2011, publicação da súmula em $17 / 11 / 2011$.

MINAS GERAIS. Tribunal de Justiça do Estado de Minas Gerais. TJMG - Ação Direta Inconst. 1.0000.13.063910-7/000, Relator(a): Des.(a) Antônio Sérvulo, ÓRGÃO ESPECIAL, julgamento em 26/02/2014, publicação da súmula em 14/03/2014.

MINAS GERAIS. Tribunal de Justiça do Estado de Minas Gerais. TJMG - Ação Direta Inconst. 1.0000.13.064955-1/000, Relator(a): Des.(a) Márcia Milanez, Relator(a) para o acórdão: Des.(a) Wander Marotta, ÓRGÃO ESPECIAL, julgamento em 10/10/2014, 
publicação da súmula em 21/11/2014.

MINAS GERAIS. Tribunal de Justiça do Estado de Minas Gerais. TJMG - Ap Cível/Reex Necessário 1.0223.12.026598-6/001, Relator(a): Des.(a) Armando Freire, $1^{a}$ CÂMARA CÍVEL, julgamento em 21/03/2017, publicação da súmula em 31/03/2017.

MONEBHURRUN, Nitish et al. A definição jurídica da "comunidade". Revista de Direito Internacional, Brasília, v. 13, n. 3, 2016 p. 443-471. Disponível em: <https://www.publicacoesacademicas.uniceub.br/rdi/ article/view/4472/pdf $>$.

MULLER, Yvonne. RSE et intérêt social In: MARTINCHENUT, Kathia; QUENAUDON, René de. $\boldsymbol{L} \boldsymbol{a} \boldsymbol{R} \boldsymbol{E}$ saisie par le droit: perspective interne et internationale. A. Pedone, 2016, p. 223-232.

OIT. Conferência Geral da Organização Internacional do Trabalho. Convenção n. ${ }^{\circ} 169$ da OIT sobre povos indígenas e tribais. 7 de junho de 1989. Disponível em: <http://www.planalto.gov.br/ccivil_03/_ato20042006/2004/decreto/d5051.htm>.

ONU. Assembleia General das Nações Unidas. Rapport du Représentant spécial du Secrétaire général chargé de la question des droits de l'homme et des sociétés transnationales et autres entreprises, John Ruggie. Principes directeurs relatifs aux entreprises et aux droits de l'homme: mise en cuvre du cadre de référence «protéger, respecter et réparer» des Nations Unies. 21 mar. 2011. Disponível em: <http:// www.ohchr.org/Documents/Issues/Business/A. HRC.17.31_fr.pdf>.

ONU. Organização das Nações Unidas. Convenção sobre Diversidade Biológica. Conferência das Nações Unidas sobre Meio Ambiente e Desenvolvimento. Rio de Janeiro, jun. 1992. Disponível em: <http:// www.planalto.gov.br/ccivil_03/decreto/1998/anexos/ and2519-98.pdf $>$.

PERCIVAL, Robert V. Liability for Environmental Harm and Emerging Global Environmental Law. Maryland Journal of International Law, v. 25, p. 37, 2010. Disponível em: <https://ssrn.com/abstract=1673887>.
PINKSE, Jonatan; KUSS, Matthias; HOFFMANN, Volker H. On the Implementation of a 'Global' Environmental Strategy: The Role of Absorptive Capacity. 26 nov. 2009. International Business Review, Spring 2010. Disponível em: <https://ssrn.com/abstract $=1513862>$.

PNUD. Programa das Nações Unidas para o Desenvolvimento. Relatório do Desenvolvimento Humano 2014 - Sustentar o Progresso Humano: Reduzir as Vulnerabilidades e Reforçar a Resilência. Disponível em: $<$ http://hdr.undp.org/sites/default/files/hdr2014_ pt_web.pdf $>$.

SÁNCHEZ, Luis Enrique. Avaliação de impacto ambiental: conceitos e métodos. 2 ed. São Paulo: Oficina de Textos, 2013, p. 477.

SANTA CATARINA. Tribunal de Justiça de Santa Catarina. TJSC, Agravo de Instrumento n. 2011.031493-4, de Garopaba, rel. Des. Pedro Manoel Abreu, Terceira Câmara de Direito Público, j. 04-062013.

TRIBUNAL MONSANTO. Tribunal Internacional Monsanto. Avis Consultatif. La Haye, 18 abr. 2017. p. 19. Disponível em: <http://fr.monsantotribunal.org/ upload/asset_cache/180671266.pdf $>$.

YANG, Tseming; PERCIVAL, Robert V. The Emergence of Global Environmental Law. Ecology Law Quarterly, v. 36. Research Paper n. 2009-36. Maryland Legal Studies and Vermont Law School Research Paper n. 09-09. 15 out. 2009. Disponível em: <https://ssrn.com/abstract $=1269157>$.

ZIERO, Gabriel Webber. O conceito de conduta empresarial responsável à luz dos ordenamentos jurídicos brasileiro, internacional e transnacional. Revista de Direito Internacional, Brasília, v. 13, n. 3, 2016, p. 80-94. 
Para publicar na Revista de Direito Internacional, acesse o endereço eletrônico www.rdi.uniceub.br ou www.brazilianjournal.org.

Observe as normas de publicação, para facilitar e agilizar o trabalho de edição. 